\title{
The Role of Media Consumption on Physical Activity Based on Health Pattern in Iranian Students by Pender's Model
}

\begin{abstract}
Background and Objective: This study investigated the role of media consumption on physical activity based on health pattern in Iranian.The method of this research was descriptive correlation with Structural Equation Method.

Materials and Methods: The statistical population of this study consisted of all students aged $11-19$ years in the whole country that 384 students were selected as statistical sample by cluster random sampling method. Two media consumption and physical activity based on health pattern Pender Were used to collect the research data. The formal and content validity of the questionnaires were confirmed and their reliability was obtained using Cronbach's alpha method 0.934 and 0.834 , respectively. For data analyzing by SPSS software and Amos software of Kolmogorov-Smirnov test, Pearson correlation coefficient and structural equation modeling were used.

Results: The results showed that media consumption had a positive and significant effect $(P=0.001)$ on Physical Activity behaviour (Beta $=0.82$ ), Exercise Benefits (Beta $=0.80$ ) and Exercise self-efficacy (Beta $=0.74$ ) and Exercise Barriers (Beta=- 0.61). Conclusion: Therefore, it can be said that media consumption improves the level of physical activity based on students' health patterns. So, it is recommended that the media, especially sports media, pay special attention to children in their programs. Keywords: Media consumption, physical activity based on health pattern, Students, Iran

Paper Type: Research Article.
\end{abstract}

Citation (Vancouver): Anari Gh, Ghasemi H, Farahani A. The Role of Media Consumption on Physical Activity Based on Health Pattern in Iranian Students by Pender's Model. Iran J Health Educ Health Promot. Spring 2020;8(2): 172-186. [Persian]x

- Citation (APA): Anari Gh., Ghasemi H., Farahani A. The Role of Media Consumption on Physical Activity Based on Health Pattern in Iranian Students by Pender's Model. (Summer 2020). Conc... . Iranian Journal of Health Education \& Health Promotion., 8(2), 172-186. [Persian]

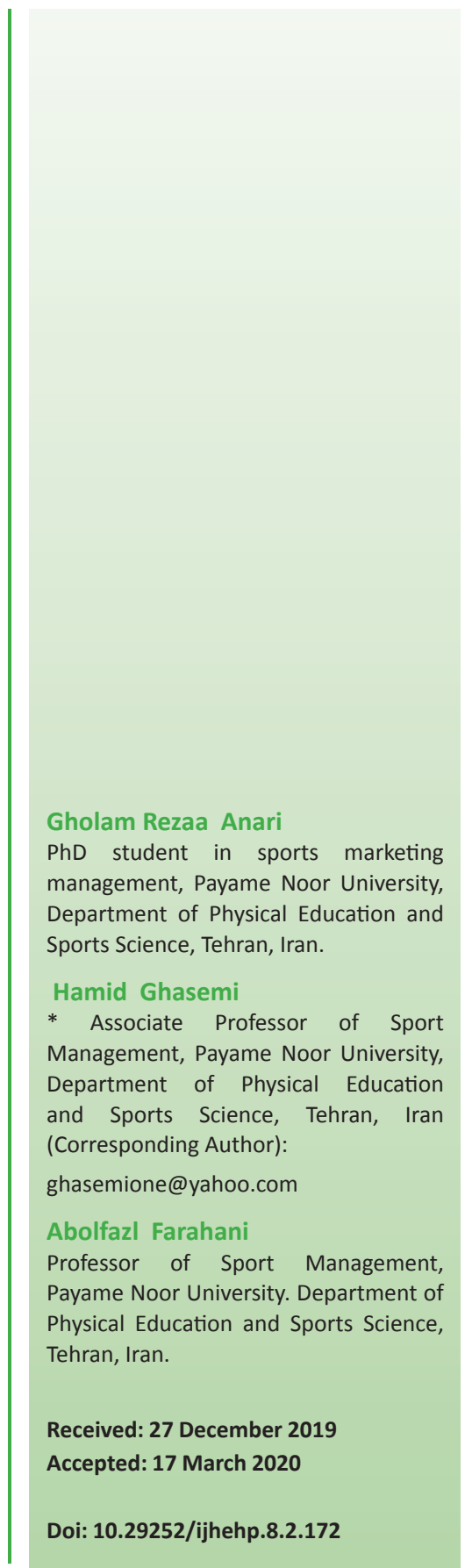




\section{نقش مصرف رسانهاى بر انجام فعاليت بدنى براساس التّوى يندر در دانش آموزان ايران با ارائه التكوى كاربردى}

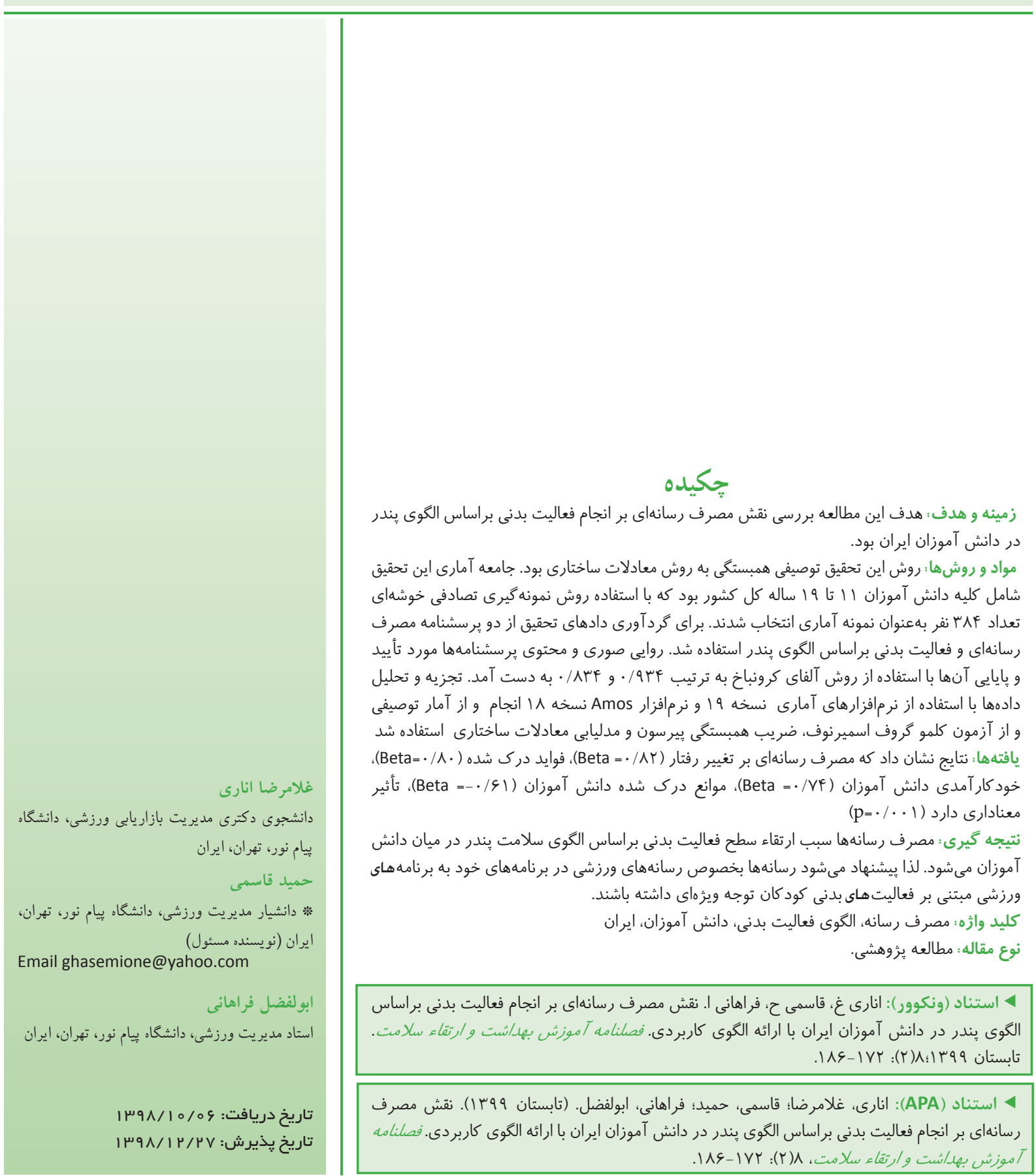


رفتار رويكرد اكولوزيكال داشته كه فاكتورهاى درون فردى، بين فردى،

سازمانى و اجتماعى را در نظر مى گيرد، به نظر مىرسد در شناسايى عوامل مؤثر در ايجاد و حفظ اين رفتار كمك كننده باشد (V). اين الكو شامل سه گروه از مفاهيم شامل تجربيات و خصوصيات فردى، احساسات و شناختهاى اختصاصى رفتار و رفتارهاى فورى محتمل الوقوع مىباشد (II). تجربيات و خصوصيات فردى در بركيرنده دو سازه رفتارهاى مرتبط قبلى و فاكتورهاى شخصى بوده و به صورت مستقيم و غيرمستقيم از طريق احساسات و شناختها،

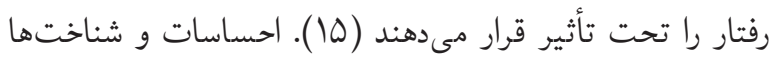
شامل سازههاى فوايد درك شده، موانع درك شده عمل، خودكارآمدى تصى درك شده، احساس مرتبط با رفتار، تاثيرگذارندههاى بين فردى و و

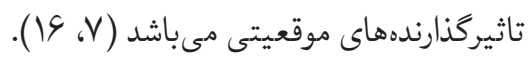
يكى از روشهاى آموزش فعاليتهاى ورزشى و و بالا بردن

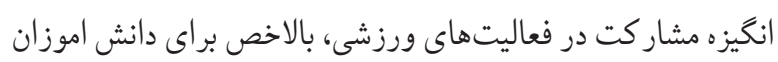

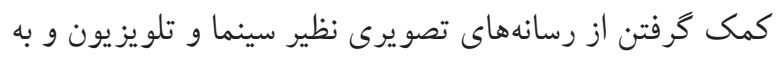
ويزه نمايش فيلمهاى آموزشى است كه يكى از روشهاى مؤى مؤثر

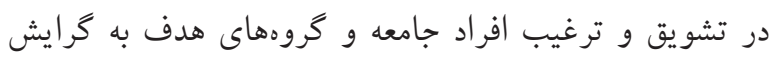

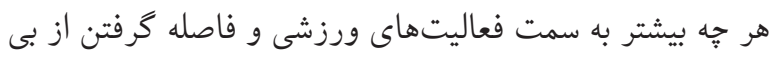

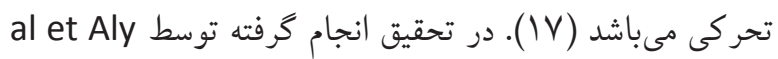
نشان داده شده كه به كاركيرى رسانههاى تصويرى نظير نمايش فيلم در آموزش مخاطبان و بيماران بسيار مفيد بوده است (1) (1).

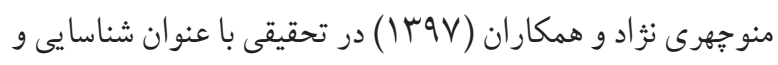

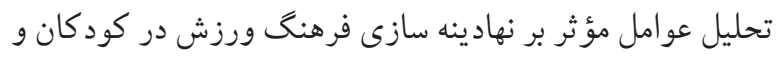

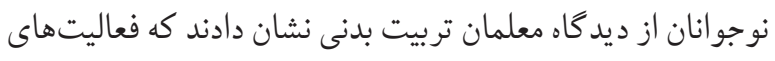

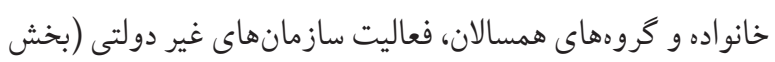
خصوصى و سازمانهاى مردم نهاد، فعاليت نهادهاى دولتى (سازمانهاى

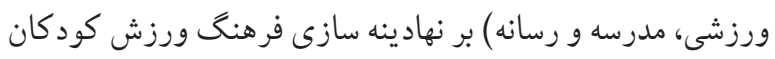

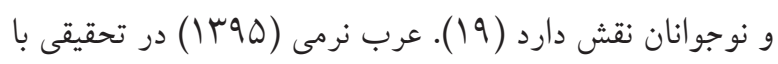

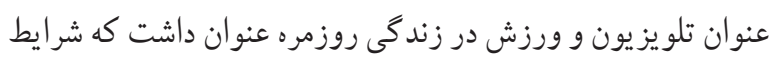

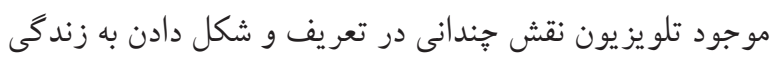

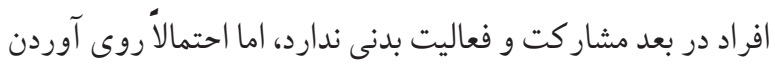
فعاليت بدنى منظم به عنوان يكى از شاخصهاى سلامت جوامع، باعث تعديل عوامل خطر بيمارىهاى قلبى عروقى شده و باعث

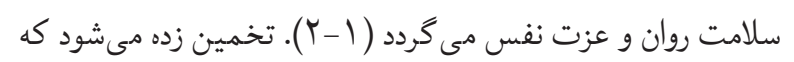

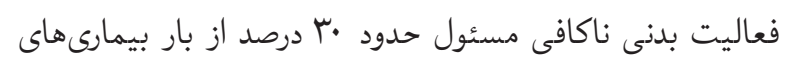

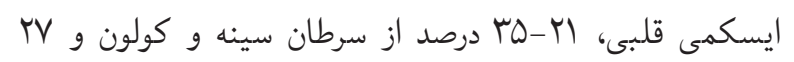

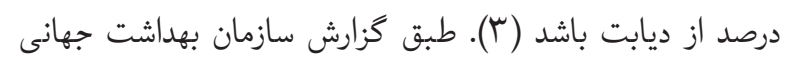

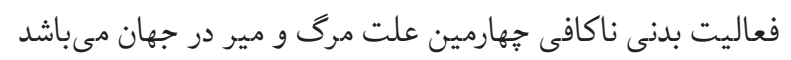
(ץ). بنابراين فعاليت بدنى منظم براى بهبود سلامت عمومى و بهاتيه

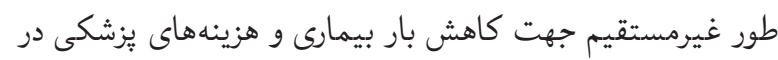

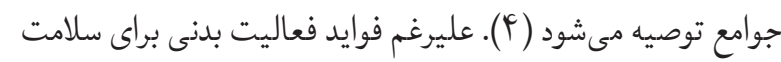

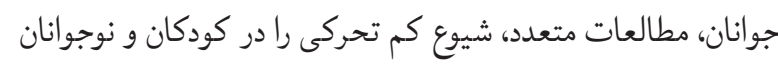

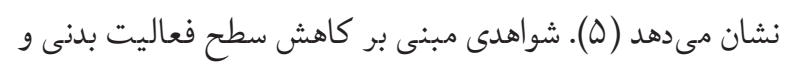

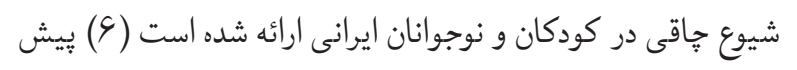

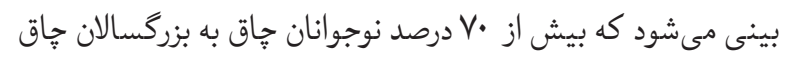

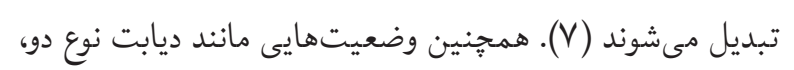

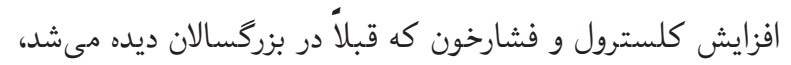

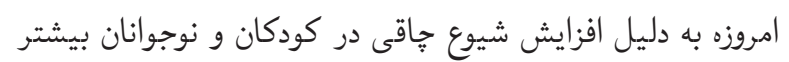

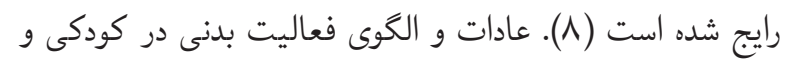

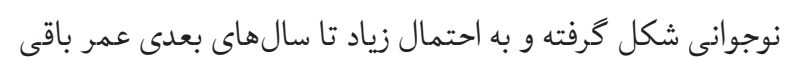

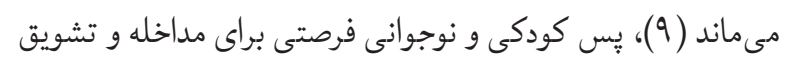

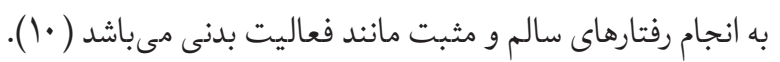

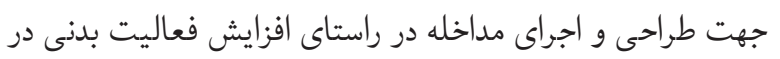

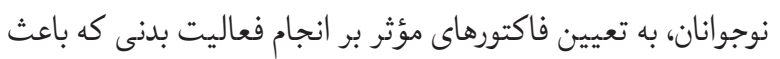

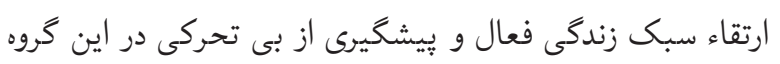

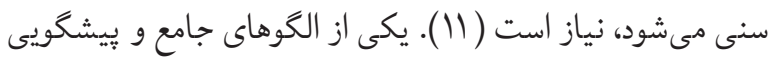

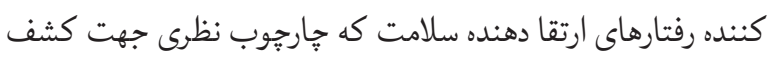
فاكتورها و عوامل مؤثر بر رفتارهاى ارتقاء سلامت ايجاد مينمايد،

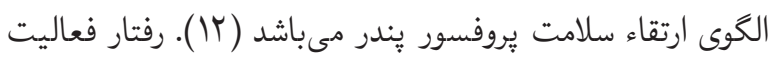

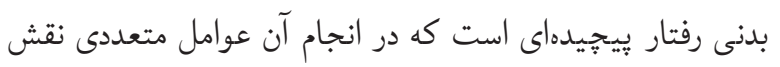
بازى مى كنند (سا) و از آنجايى كه اين الكو جهت ايجاد تغيير 
القول هستند. دراين ميان نتياج ضدونقيصى به دست آمده وى

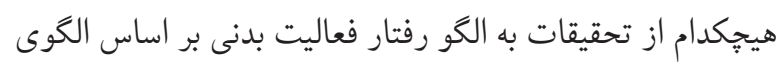
ارتقاى سلامت يرداخته نشده است.

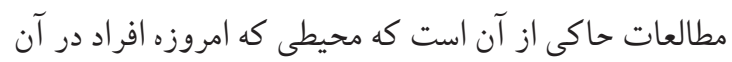
به سر مى برند، عمدتاً محيطى است كه تحت تأثير عملكر د رسانهها

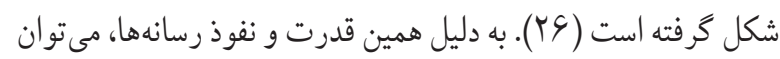
كفت كه رسانها نقش هدايت گرى و راهنمايى افر اد را در تصميم

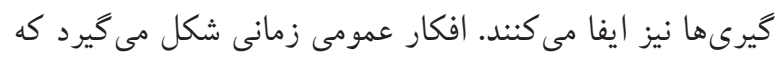

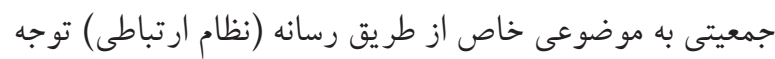

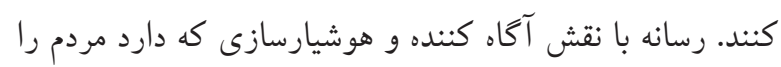

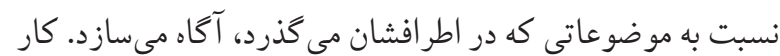

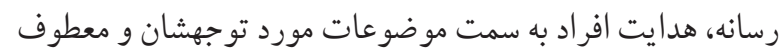

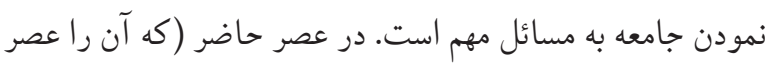

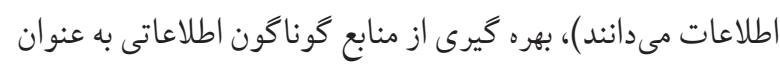
منابع مختلف تغذيه فكرى بشر مورد توجه قرار كرفته است. جوامع

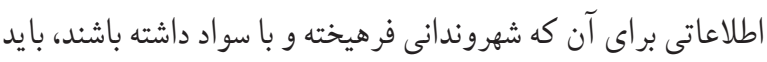

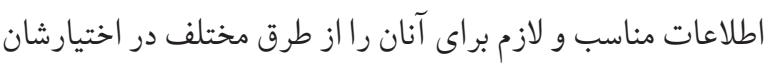

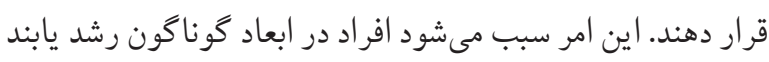

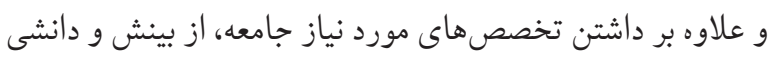

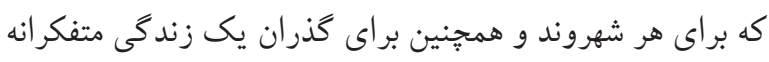

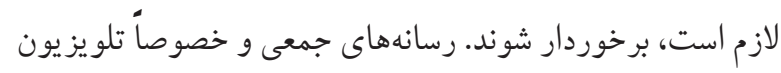

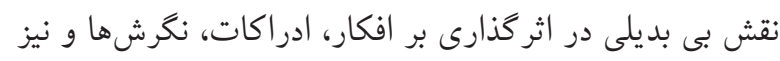

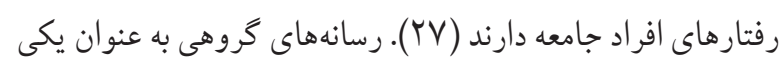
از عوامل بسيار مهم اجتماعى كردن مطرح هستند (Y^). رسانهها

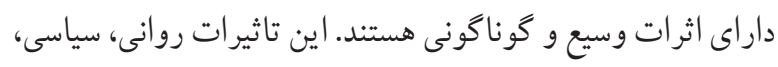

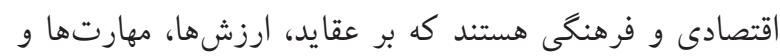

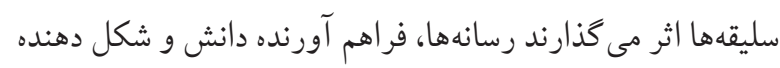

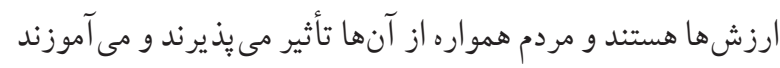

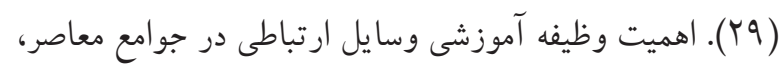

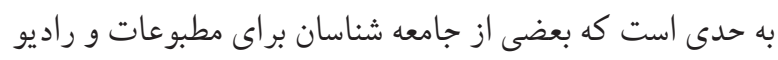

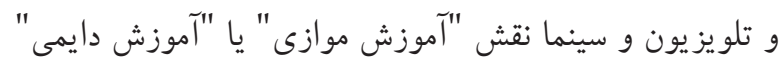

مخاطبان در شكل دهى و زمان بندى برنامهاى ورزشى تلويزيون و

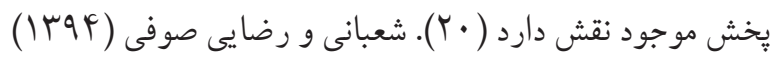

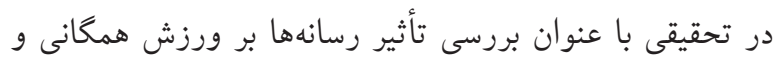

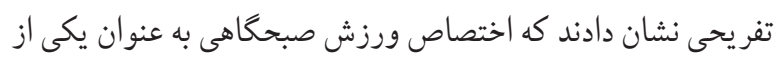

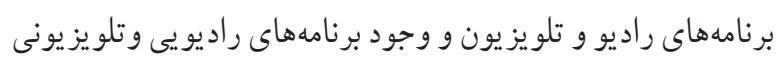

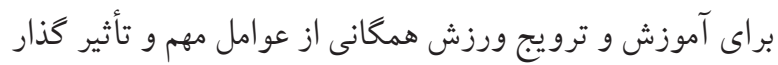

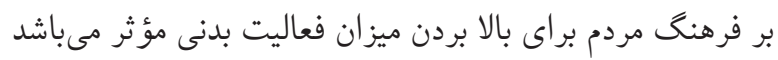

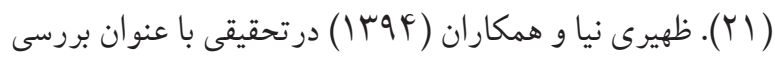

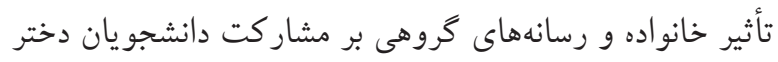
در فعاليتهاى ورزشى دانشجو يان دختر دانشخاه هرمز كان نشان

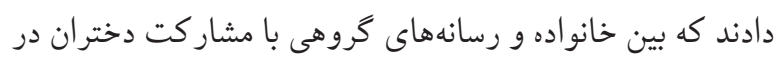

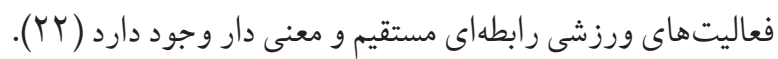
et al Geraee

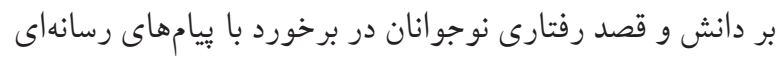

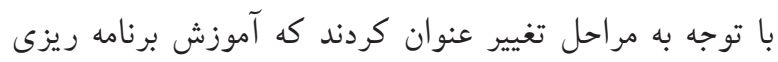

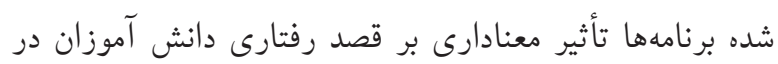

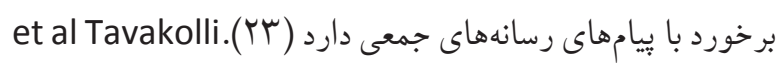

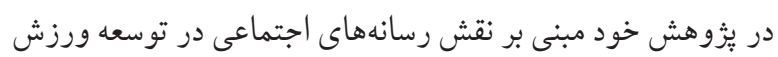

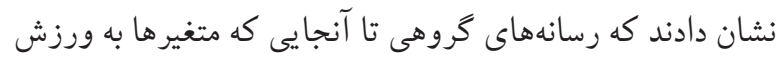

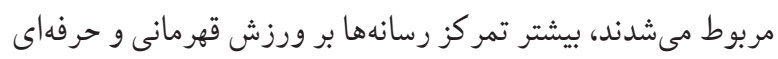

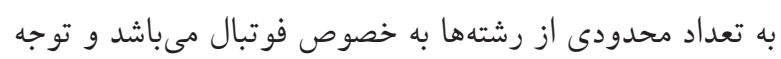

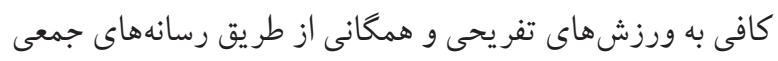

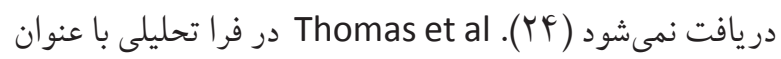

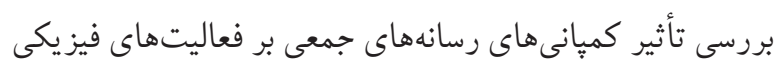

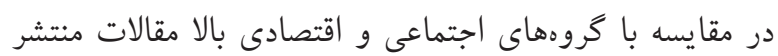

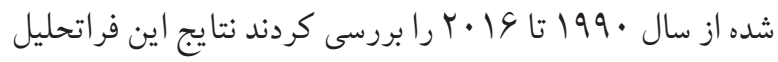
مبين اين بود كه نقش رسانههاى جمعى اثرات ناعادلانهاى بر اقشار

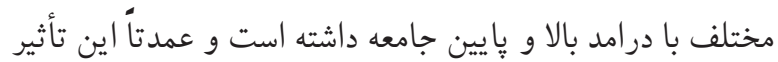

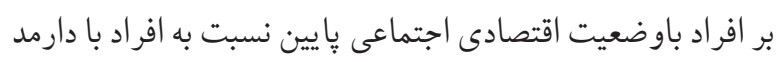

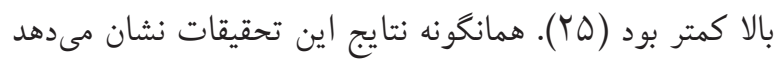

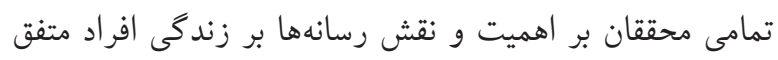


زمينه هاى مختلف بين كروههاى اجتماعى جامعه ما ديكر جوامع، بر

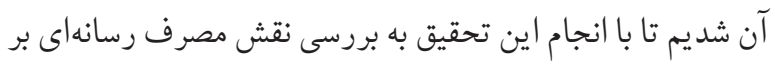

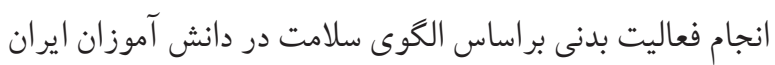

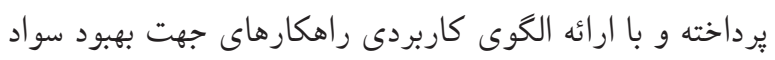

$$
\text { حركتى و فعاليتهاى بدنى بيشتر ارائه شود. }
$$

مو اد و روش ها بر مبناى نظريه يِيازه فرايند يُزوهش (ها؟)، روش اين تحقيق از

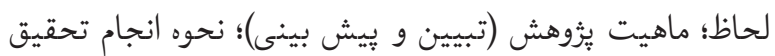

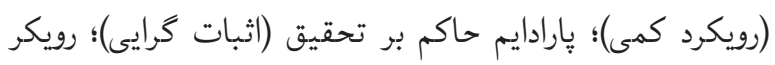

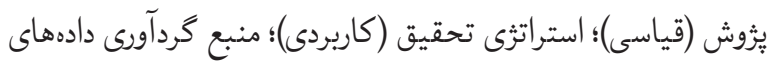
تحقيق (مطالعات كتابخانهاى، ميدانى)؛ روش تجزيه و تحليل دادهها تحقيق (روش يابى معادلات ساختاري) بود. جامعه امارى اين تحقيق

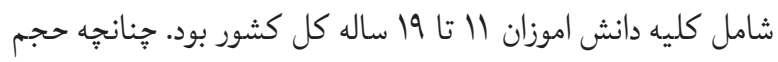

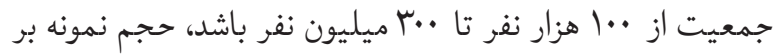

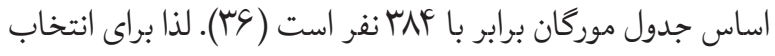

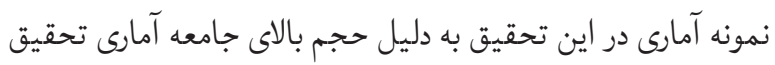

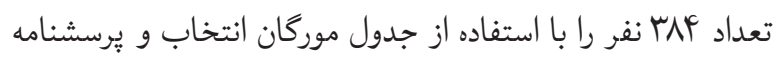
در اختيار انها قرار گرفت روش نمونه خيرى در اين تحقيق به دليل

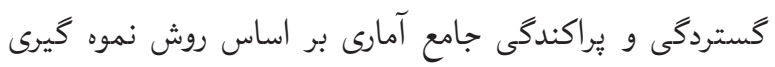

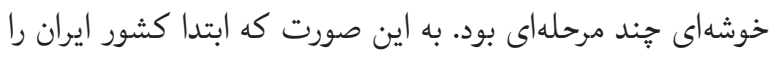

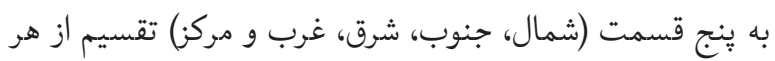

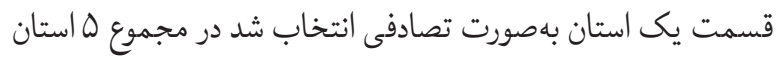

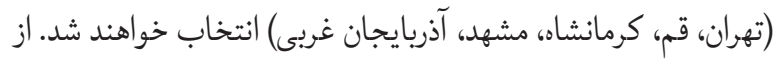
هر استان دو شهر ( •ا شهر) بهصورت تصادفى انتخاب و از هر شهر

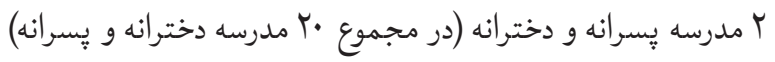

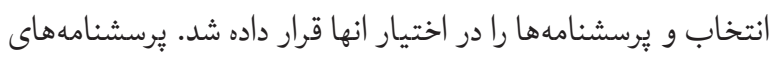

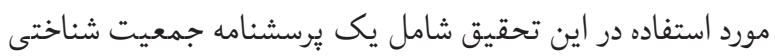
و دو يرسشنامه مىباشد به شرح ذيل مىباشد:

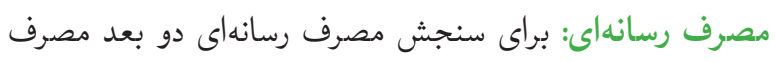
رسانهایى داخلى و مصرف رسانهاى خارجى در نظر گرفته شد.
قائل هستند (·ץ). جامعه شناسان معتقدند كه وسايل ارتباطى با يخش اطلاعات و معلومات جديد، به موازات كوشش معلمان و هوله

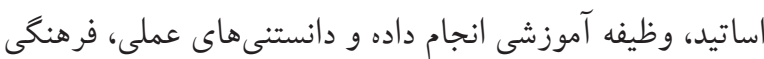
و اجتماعى دانش آموزان و دانشجويان را تكميل مى كنند ( آ⿱艹).

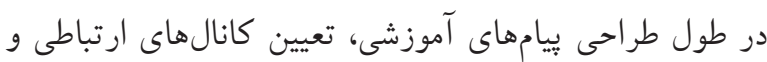

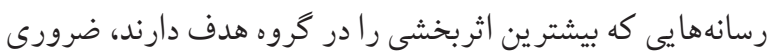

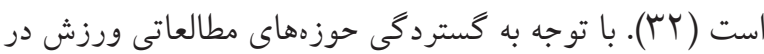

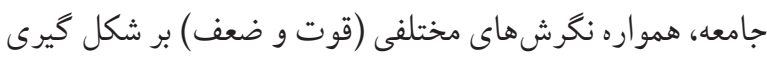

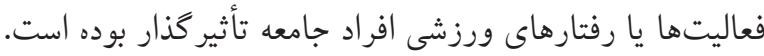

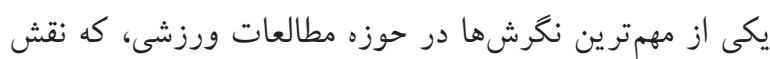

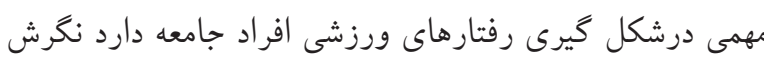

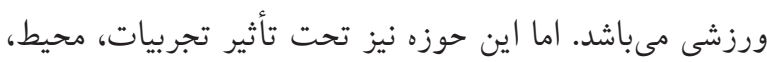

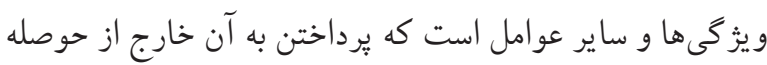

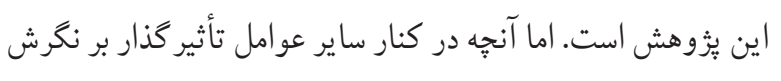
ورزشى، از اهميت بالايى برخوردار است، موضوع و مبحث رسانهها

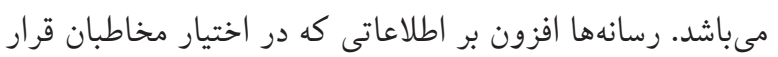

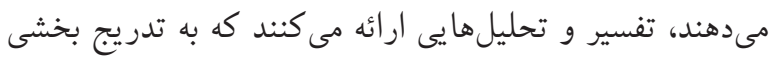

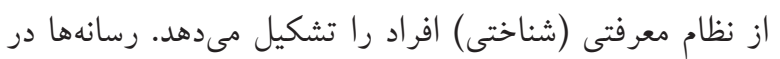

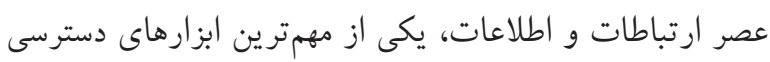
به اهداف تلقى مىشوند و مصرف و كاربرد انواع آنها از جهات كوناگون و در ميان گروههاى مختلف اجتماعى مورد توجه قرار

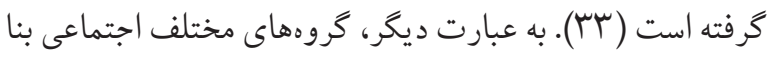
بر متغيرهاى مختلف اجتماعى فرهنكى به گونهاى با رسانهها بيوند

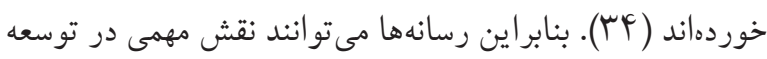
ورزش و تفكر ورزشى داشته باشند. رسانها با پخش خبرهاي صحيح و واقع گرايانه و ارائه راهكارهاى مناسب در در بين مرددم مى تو انند نقش راهبردى براى ورزش داشته باشند و به همه فعالان

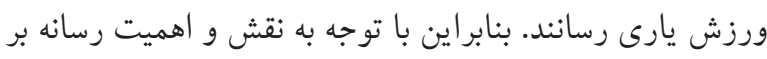

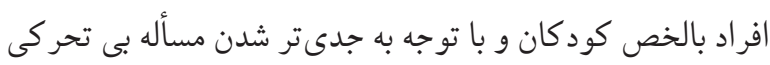

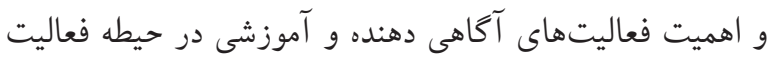

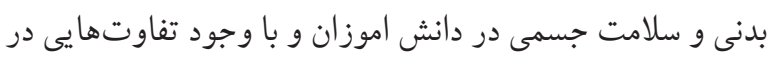


يك (خيلى كم) تا ينج (خيلى زياد) شماره كذارى شده است. حداقل

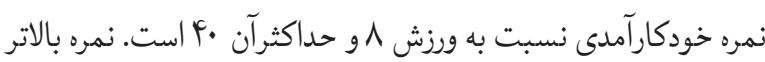

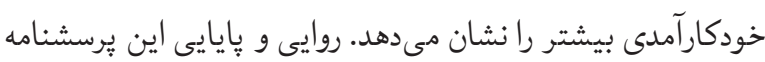

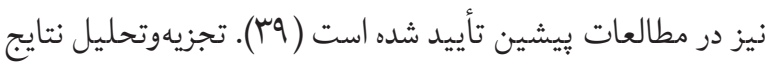

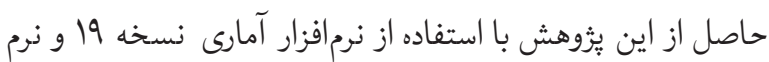
افزار Amos نسخه 1 ا در دو سطح توصيفى و استنباطى انجام

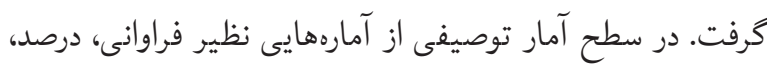

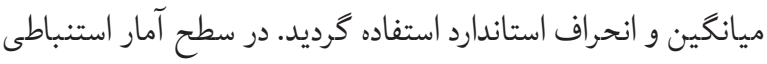
از آزمون كلمو كروف اسميرنوف براى تعيين نرمال بودن دادهها، ضريب همسبتخى بيرسون و مدليابى معادلات ساختارى استفاده

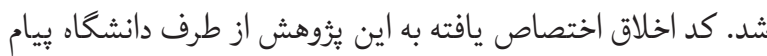
نورتهوان IR.PNU.REC.1398.183 مى باشد. نتايج جدول انشان داد كه •م درصد نمونه مورد مطالعه دختر

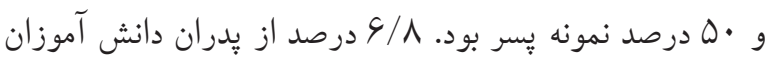

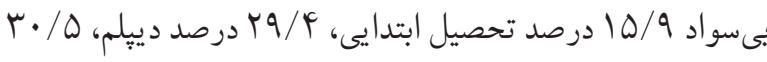
درصد فوق دييلم، IV/F درصد ليسانس و بالاتر داشتند. و ودرصد از

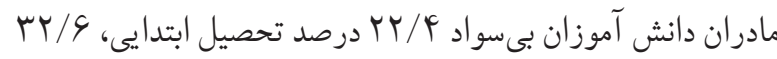

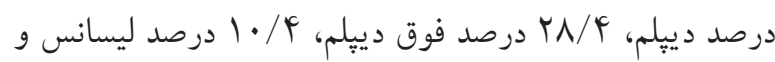

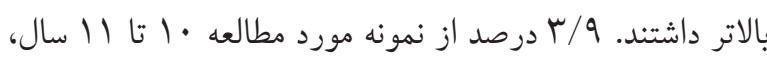

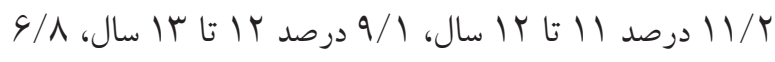

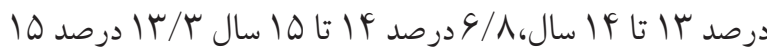

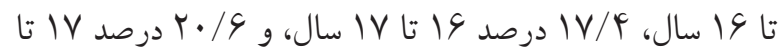

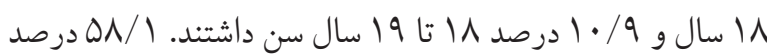

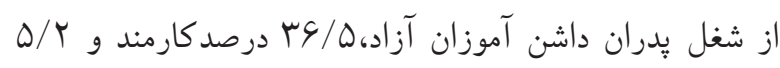

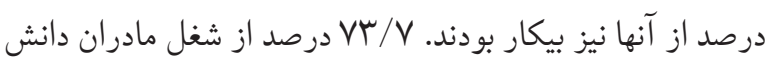

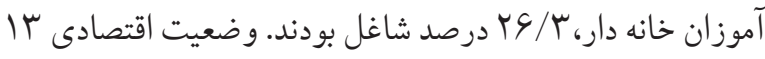

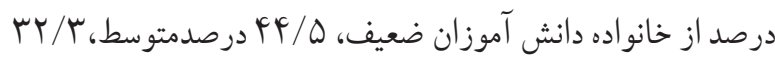
درصدخوب و ٪/ • ا درصدوضعيت اقتصادى بسيار خوب داشتند.

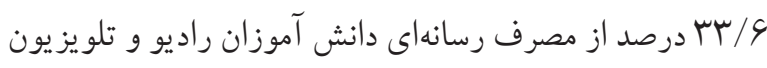

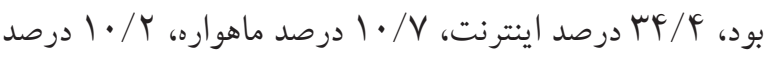

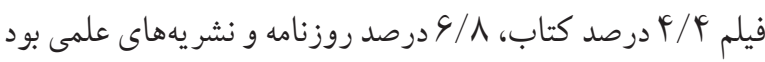

در هر يك از اين ابعاد از افراد خواسته شده تا ميزان مصرف و نوع برنامه مورد استفاده خود را ذكر نمايند. ير يُشامه فعاليت بدنى براساس الكَوى ارتقاى سلامت جهت بررسى فعاليت بدنى بر اساس الكوى ارتقاى سلامت از برأ

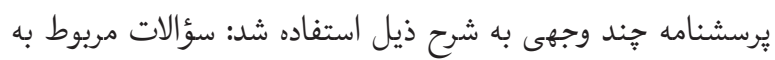
مراحل تغيير رفتار فعاليت جسهى كه از برسشناهه (A Physical

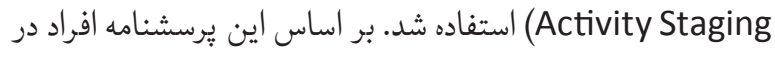

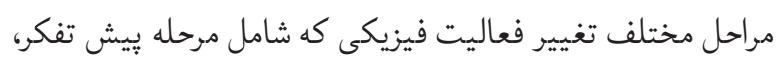
تفكر، آمادكى، عمل و حفظ و نكهداري است طبقه بندى مى مشوند.

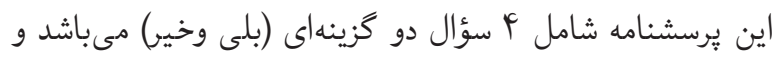

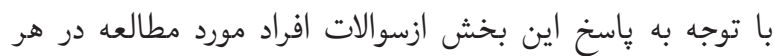
يك از مراحل تغيير رفتار فعاليت جسمى طبقه بندى مىشوند.

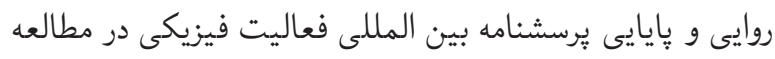

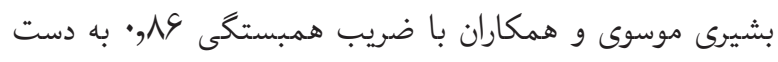

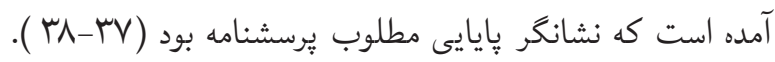
بخش دوم سؤالات مريوط به فوايد درك شده و موانع درك شده

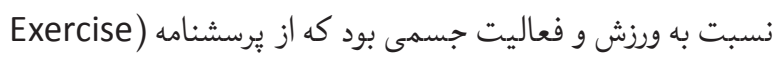
(Benefits/Barriers Scale

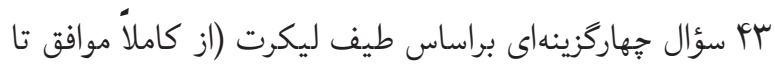

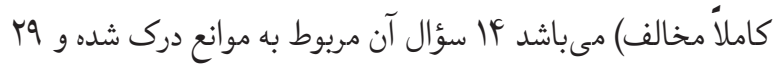

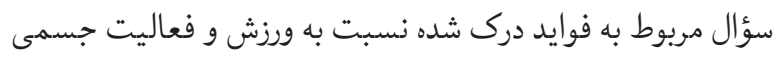

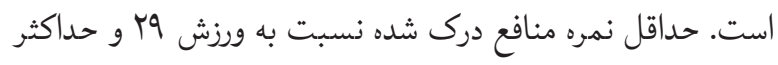

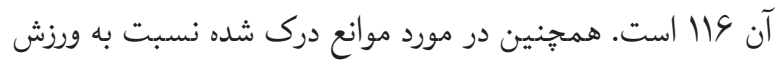

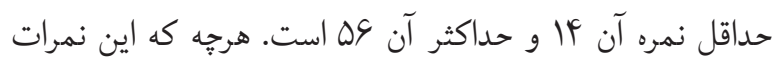

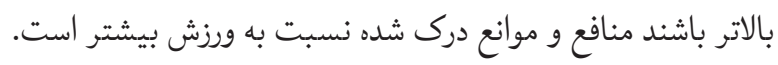

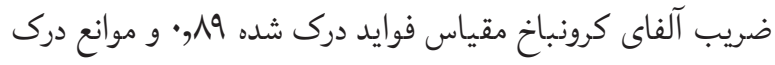

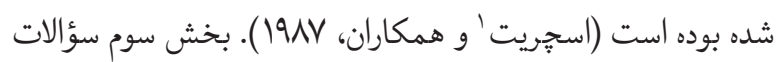
مربوط به خودكارآمدى بود. براى تعيين خودكارآمدى از برسشنامه

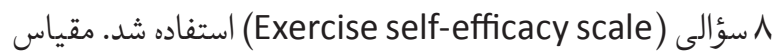
ياسخكويى به برسشنامه بر اساس طيف ليكرت ها درجهاى بود كه از 


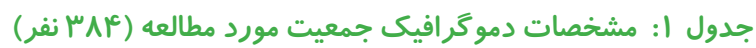

\begin{tabular}{|c|c|c|c|c|c|c|c|}
\hline درصد & فراوانى & متغير & & درصد & فراوانى & متغير & \\
\hline$\% \Delta \wedge / 1$ & שז' & آزاد & \multirow{3}{*}{ شغل پيدر } & $\%$ & $19 r$ & دختر & \multirow{2}{*}{ جنسيت } \\
\hline \% & If. & كارمند & & $\% \Delta$ & 194 & 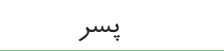 & \\
\hline$\% \Delta / r$ & $r$. & بيكار & & $\% / 1 \wedge$ & rG & بى سواد & \multirow{5}{*}{ تحصيلات پِر } \\
\hline$\% \vee \mu / V$ & rᄉr & خانه دار & \multirow{2}{*}{ شغل مادر } & $\% 10 / 9$ & \&1 & ابتدايى & \\
\hline \% & $1 \cdot 1$ & شاغل & & $\%$ \%q/F & 111 & دييلم & \\
\hline \% & $\Delta$. & ضعيف & \multirow{4}{*}{ وضعيت اقتصادى } & $\%$ & 118 & فوق ديڤلم & \\
\hline$\% F F / D$ & $|V|$ & متوسط & & $\% 1 V / F$ & $S V$ & ليسانس و بالاتر & \\
\hline 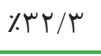 & ITF & خوب & & $\% .9$ & r & بى سواد & \multirow{5}{*}{ تحصيلات مادر } \\
\hline$\% 1 \cdot / r$ & rq & بسيار خوب & & \%rr/f & 19 & ابتدايى & \\
\hline$\% / / \wedge$ & rs & זו تا fl سال & \multirow{6}{*}{ سن } & 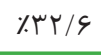 & iro & دييلم & \\
\hline$\% 9 / 1$ & rs & fا تا ها سال & & $\%$ YN/F & 1.9 & فوق دييلم & \\
\hline 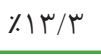 & 01 & ها تا \&1 سال & & $\% 1 \cdot / 4$ & r. & ليسانس و بالاتر & \\
\hline$\% I V / F$ & $S V$ & ع| تا VIV سال & & \% & 10 & •ا تا || سال & \multirow{3}{*}{ سن } \\
\hline$\% r \cdot / 4$ & $\sqrt{9}$ & Vا تا 1 1 سال & & $\% 11 / r$ & F & | & \\
\hline$\% 1 \cdot 19$ & pr & 11 تا 19 سال & & $\% 9 / 1$ & mo & זו تا سا سال & \\
\hline$\% 1 \cdot / r$ & rq & فيلم & \multirow{3}{*}{ رسانه مصرفى } & ع/s & 1199 & راديو و تلويزيون & \multirow{3}{*}{ رسانه مصرفى } \\
\hline$\% \bar{q} / \mathcal{F}$ & IV & كتاب & & $\% \mu r / f$ & ruו & اينترنت & \\
\hline$\% 9 / \wedge$ & rs & روزنامه-نشريه & & $\% \cdot / V$ & \&1 & ماهواره & \\
\hline
\end{tabular}

روايى سازهاى برسش نامه با استفاده از تكنيك تحليل عاملى ساختارهاى گشتاورى' (AMOSv.18) و بستهى آمارى براى علوم

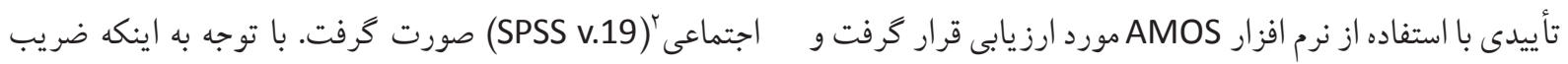

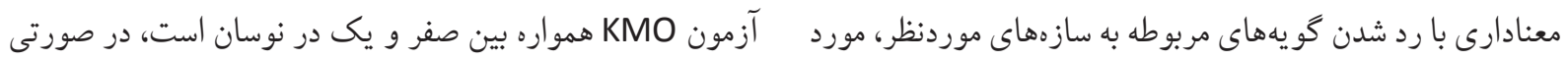

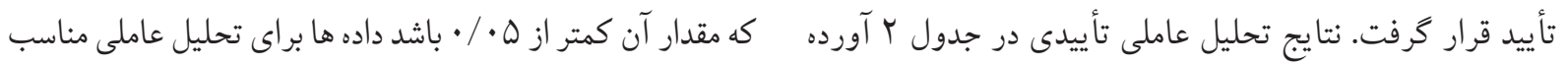

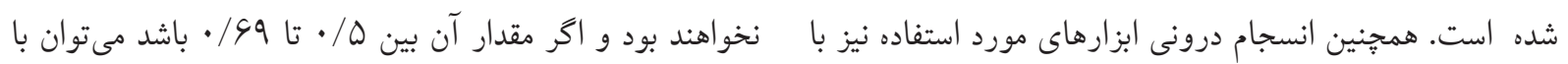

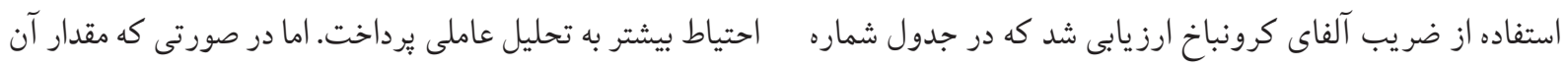

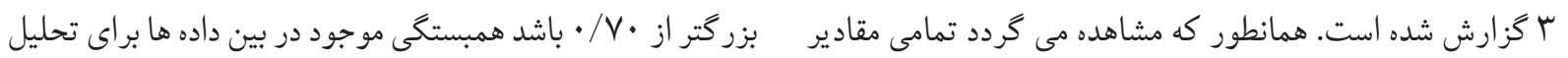

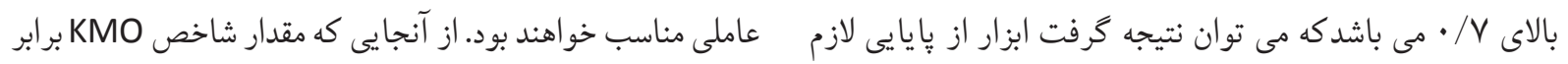

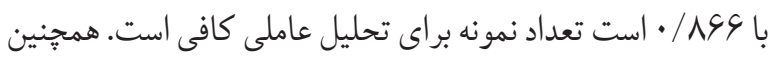

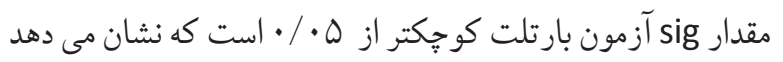

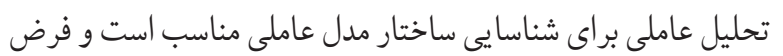

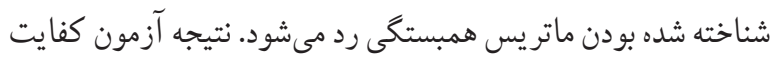

1. Analysis of Moment Structures-AMOS

2. Statistical Package for Social Sciences-SPSS

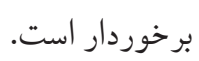

به منظور تجزيه و تحليل دادهها روشهاى مختلف تحليل آمارى، نظير تحليل همبستخى بيرسون براى محاسبهى ضرايب همبستكى

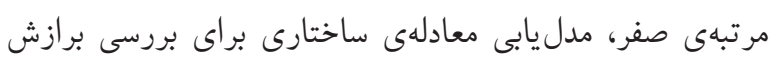
الخوى معادلهى ساختارى با دادههاى -جمع آورى شده مورد استفاده معادي قرار گرفت. تحليلهاى مورد نظر با استفاده از نرمافزارهاى تحليل 
جدول r: نتايج تحليل عاملى تأييدى (CFA) براى سؤالات تحقيق

\begin{tabular}{|c|c|c|c|c|c|c|c|c|c|}
\hline نتيجه & معنادارى & $\begin{array}{c}\text { وزن ركرسيونى عاملى) } \\
\text { (بارى }\end{array}$ & كويه & متغير & نتيجه & معنادارى & 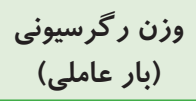 & كويه & متغير \\
\hline معنادار & $\cdot / \ldots$ & $\cdot / \Delta V$ & q32 & \multirow{31}{*}{ انجام فعاليت } & معنادار & $\cdot / \cdots$ & .190 & $\mathrm{q} 1$ & \multirow{6}{*}{ رصانه } \\
\hline معنادار & $\cdot / \ldots$ &.$/ S V$ & q33 & & معنادار & $\cdot / \ldots$ & $\cdot / V$ & $q 2$ & \\
\hline معنادار & $\cdot / \ldots$ & .199 & q34 & & معنادار &.$/ \ldots$ & $\cdot / V$ & q3 & \\
\hline معنادار &.$/ \ldots$ & • & q35 & & معنادار & $\cdot / \ldots$ & $\cdot / \Delta F$ & $q 4$ & \\
\hline معنادار & $\cdot / \cdots$ & $\cdot / s q$ & $q 36$ & & معنادار & $\cdot / \cdots$ & $\cdot / \vee q$ & q5 & \\
\hline معنادار &.$/ \ldots$ & .190 & $q 37$ & & معنادار & $\cdot / \ldots$ & $\cdot / 1 \Delta \Delta$ & $q 6$ & \\
\hline معنادار & $\cdot / \ldots$ & .199 & q38 & & معنادار & $\cdot / \ldots$ & $\cdot / V I$ & q7 & \\
\hline معنادار &.$/ \ldots$ & $\cdot / \Delta \Delta$ & q39 & & معنادار & $\cdot / \ldots$ & $\cdot / V M$ & q8 & \\
\hline معنادار & $\cdot / \ldots$ & $\cdot / \mathbb{F} \wedge$ & $\mathrm{q} 40$ & & معنادار & $\cdot / \ldots$ & $\cdot / 1 \Delta \Delta$ & q9 & \\
\hline معنادار &.$/ \ldots$ & • / & q41 & & معنادار & $\cdot / \ldots$ & $\cdot / \wedge \Lambda$ & q10 & \\
\hline معنادار &.$/ \ldots$ & $\cdot / \Delta S$ & $q 42$ & & معنادار &.$/ \ldots$ & . / & q11 & \\
\hline معنادار & $\cdot / \ldots$ & .194 & q43 & & معنادار & $\cdot / \ldots$ & $\cdot / \& r$ & $q 12$ & \\
\hline معنادار & $\cdot / \ldots$ & .109 & q44 & & معنادار & $\cdot / \cdots$ & $\Delta V$ & q13 & \\
\hline معنادار & $\cdot / \ldots$ & . / Or & q45 & & معنادار & $\cdot / \ldots$ & $\cdot / s r$ & q14 & \\
\hline معنادار & $\cdot / \ldots$ & $\cdot / \Delta S$ & q46 & & معنادار & $\cdot / \ldots$ & . & q15 & \\
\hline معنادار & $\cdot / \ldots$ & $\cdot / \Delta \Lambda$ & $q 47$ & & معنادار &.$/ \ldots$ &.$/ 8 \wedge$ & q16 & \\
\hline معنادار & $\cdot / \cdots$ & .10 & $q 48$ & & معنادار &.$/ \ldots$ & .190 & q17 & \\
\hline معنادار &.$/ \ldots$ &.$/ 91$ & q49 & & معنادار &.$/ \ldots$ &.$/ s r$ & q18 & \\
\hline معنادار & $\cdot / \cdots$ & .190 & q50 & & معنادار &.$/ \ldots$ &.$|9|$ & q19 & لدنح \\
\hline معنادار & $\cdot / \cdots$ & . / $q r$ & q51 & & معنادار & $\cdot / \cdots$ & $\cdot / \Delta \Lambda$ & $q 20$ & 0. \\
\hline معنادار & $\cdot / \ldots$ &.$|9|$ & $q 52$ & & معنادار & $\cdot / \ldots$ &.$|4|$ & $q 21$ & \\
\hline معنادار &.$/ \ldots$ & .190 & $q 53$ & & معنادار &.$/ \ldots$ & .101 & $q 22$ & \\
\hline معنادار & $\cdot / \cdots$ & $\cdot / \Delta \Delta$ & $q 54$ & & معنادار &.$/ \ldots$ &.$/ A \mu$ & $q 23$ & \\
\hline معنادار &.$/ \ldots$ & $\cdot / 9$ & q55 & & معنادار & $\cdot / \cdots$ & $\cdot / 9 V$ & $q 24$ & \\
\hline معنادار &.$/ \ldots$ & 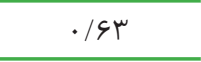 & q56 & & معنادار &.$/ \ldots$ & .194 & q25 & \\
\hline معنادار &.$/ \ldots$ &.$/ 4$ & q57 & & معنادار &.$/ \ldots$ &.$/ 9 r$ & q26 & \\
\hline معنادار & $\cdot / \ldots$ & $\cdot / \Delta V$ & q58 & & معنادار &.$/ \ldots$ & .190 & $q 27$ & \\
\hline معنادار & $\cdot / \cdots$ & .199 & q59 & & معنادار & $\cdot / \ldots$ & $\cdot / 4 q$ & $q 28$ & \\
\hline معنادار & $\cdot / \ldots$ & $\cdot / V I$ & $q 60$ & & معنادار & $\cdot / \ldots$ &.$/ 9 r$ & q29 & \\
\hline \multirow[t]{2}{*}{ معنادار } & $\cdot / \ldots$ &.$/{ }^{\prime} \mu$ & q61 & & معنادار & $\cdot / \ldots$ & $\cdot / V I$ & q30 & \\
\hline & & & & & معنادار & $\cdot / \ldots$ & $\cdot / V r$ & q31 & \\
\hline
\end{tabular}


جدول عا: آزمون كفايت دادهها

آزمون كفايت حجم نمونه كيزر-مى ير- اكلين (KMO) (KS4)

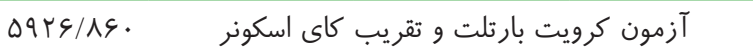

درجه آزادى $\quad$ Sig $\quad$ S...

نتايج جدول F نشان داد كه مقدار شاخص KMO برابر با 1/199 • است تعداد نمونه براى تحليل عاملى كافى است. همجنين

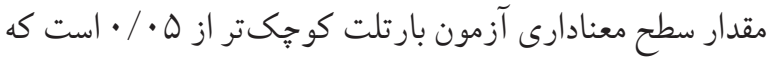

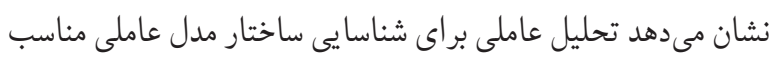
است و فرض شناخته شده بودن ماتريس همبستكى رد مى شودا.

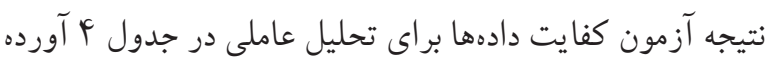

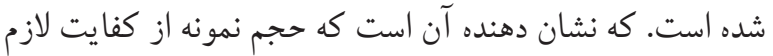
برخوردارى مىباشد. جدول ه: شاخص هاى برازش مدل

\begin{tabular}{|c|c|c|c|c|c|c|c|}
\hline NFI & GFI & TLI & CFI & RMR & RMSEA & $\begin{array}{c}\text { Chi- } \\
\text { square } \\
\text { /df }\end{array}$ & \\
\hline$\cdot / 9 \cdot r$ & . /9ro &.$/ 9 \mu \mathrm{F}$ &.$/ 9 r \wedge$ & .1 .90 & $\cdot / \cdot v^{f}$ & r/VFr & \\
\hline بزرگتر & بزرگتر & بزرگتر & بزرگتر & كمتر از & كمتر از & 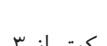 & مقادير قابل \\
\hline از از /. & . 19 ز & از ا 9 ـ. & از از /9. &.$/ \cdot 1 \Delta$ & $\cdot / \cdot \wedge \Delta$ & مدر "ג & قبول \\
\hline
\end{tabular}

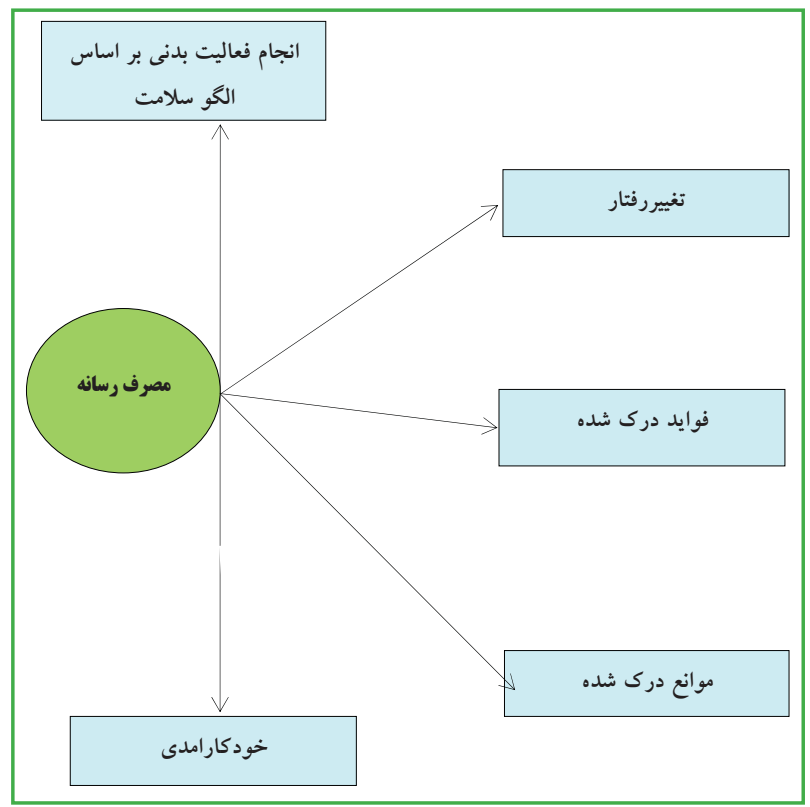

شكل ا. الكُى معادلهى ساختارى [مدل ساختارى و مدلهاى

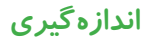

نتايج جدول Y ( تحليل عاملى تاييد) نشان داد كه، تمام گو يه هاى

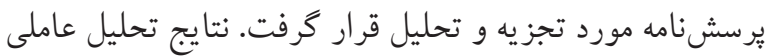

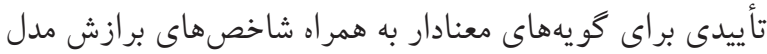

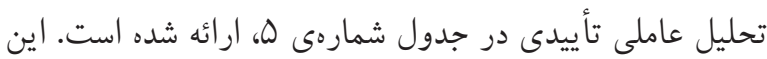

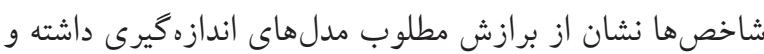

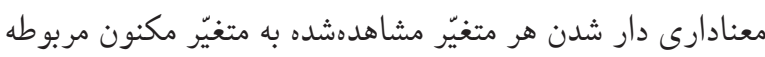
مورد تأييد قرار كرفت.

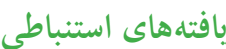
از آنجا كه يكى از بيششرطهاى به كاركيرى رويكرد متغيّرهاى

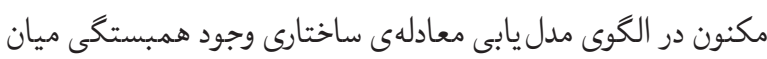
متغيّرهاى بُزوهش است، بدين منظور تحليل همبستخى يُبرسون

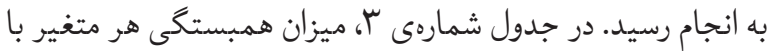

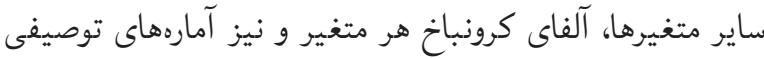
آنها شامل ميانگين و انحراف معيار، ارائه شده است.

جدول "ا: نتايج ميانغين، انحراف معيار، يايايى و همبستگى ييرسون مصرف رسانه و انجام فعاليتهاى بدنى درميان دانش آموزان

\begin{tabular}{|c|c|c|c|c|}
\hline$r$ & 1 & معيار & ميانگين & متغير ها \\
\hline- & $(\cdot / 9 \mu F)$ &.$/ 901$ & $r / \mu V r$ & مصرف رسانه \\
\hline$(\cdot / \wedge F \Delta)$ & . MYV &.$/ 911$ & $r / 991$ & انجام فعاليت بدنى \\
\hline
\end{tabular}

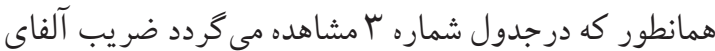

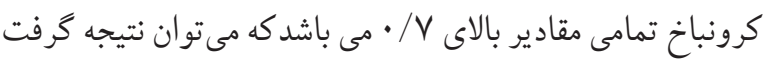

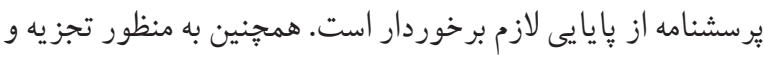

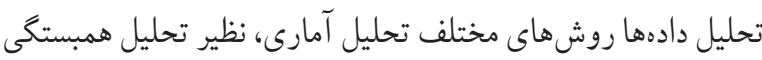

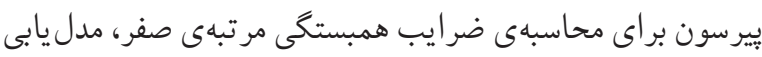

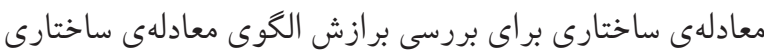

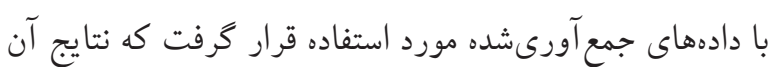

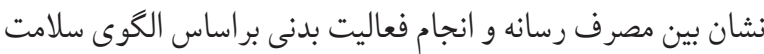
ارتباط مثبت و معنادارى وجود دارد. 

داراى قدرت قابل ملاحظه اى براى شكل دادن به عقايد و باورها،

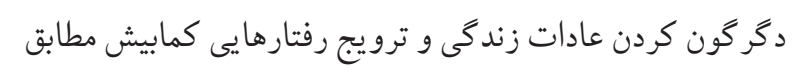
ميل كنترل كنند كان رسانه ها و محتواى آنها هستند. اين ديد كاه نداهنه

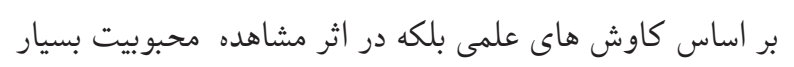

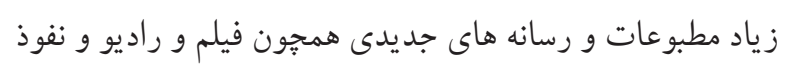

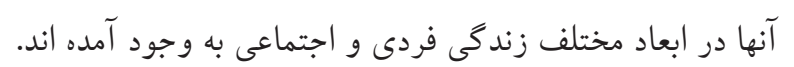

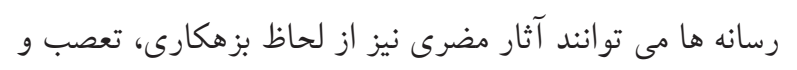

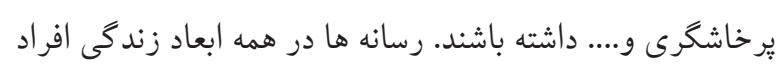

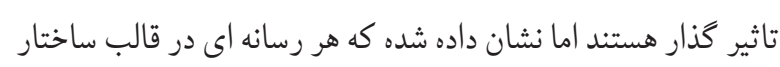

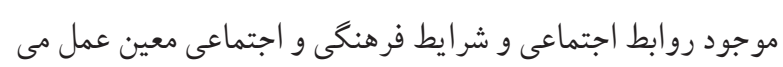

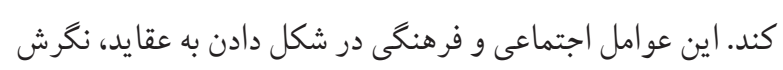

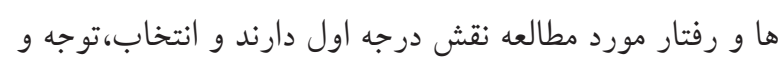

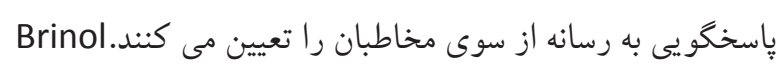
همسو با اين نتيجه بخش از تحقيق عنوان مى دارد

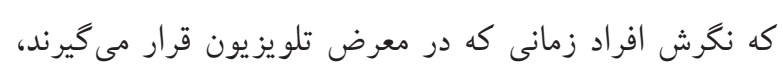

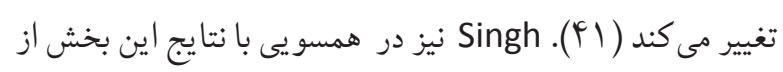

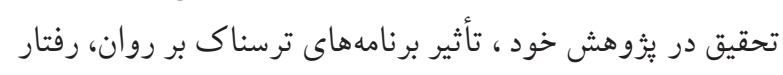

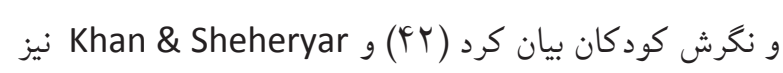

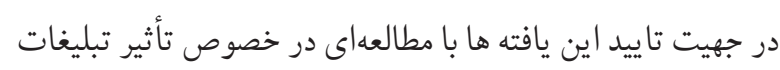

در مدل برازش يافته اثرات مستقيم به لحاظ آمارى معنادار

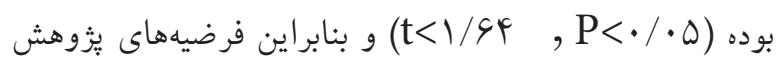

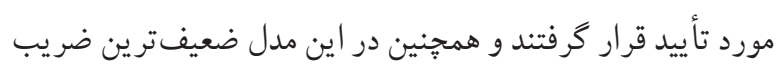

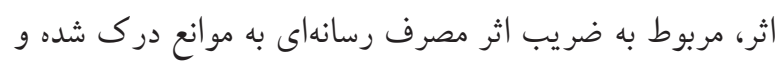

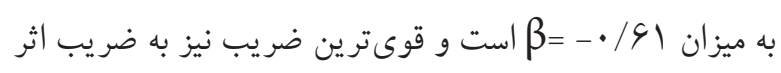

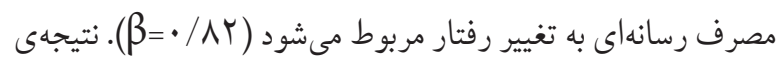

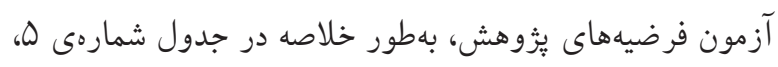
نشان داده شده است.

بحث هدف اين تحقيق بررسى تأثير مصرف رسانه بر انجام فعاليت بدنى

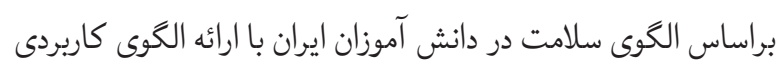

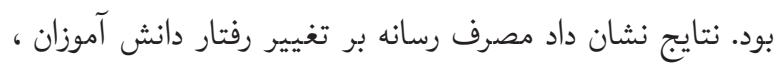

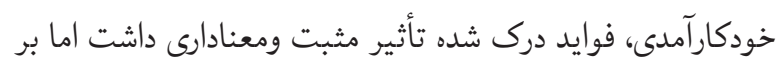
موانع درك شده تأثير منفى داشت. بخشى از نتايج اين تحقيق نشانداد كه رسانه مصرفى مى تواند بر تغيير رفتار فعاليتهاى بدنى دانش آموزان تاثير مثبت داشته نتاني

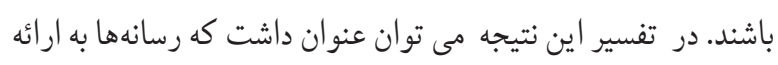
ديد كاههاى هم شكل و كم و بيش يكسان از واقعيت اجتماعى تمايل

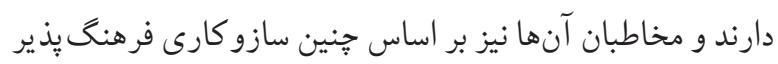

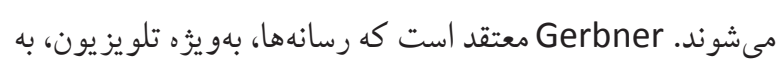

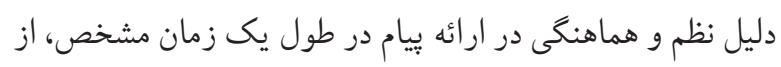

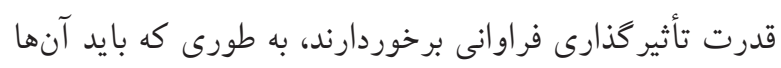

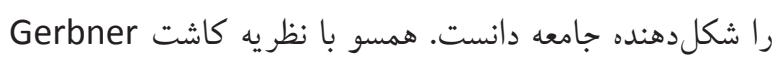

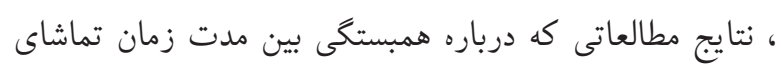

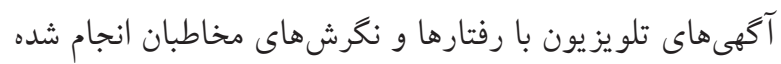

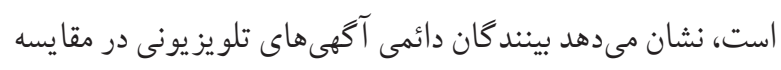

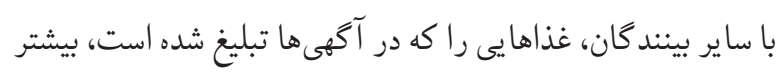

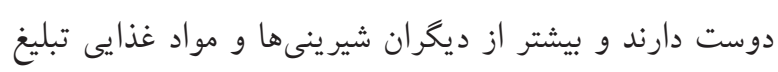

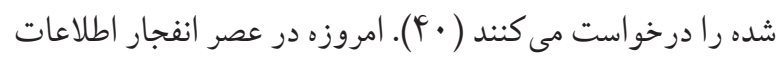

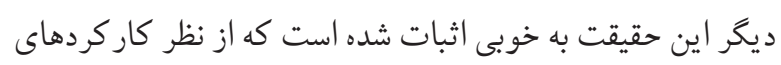


را در افزايش آكاهى مخاطبان و ييشبرد اهداف آموزشى موثر مى دانند مطابقت دارد(4) مأ). با نتيجه تحقيق . Rajaian و همكاران

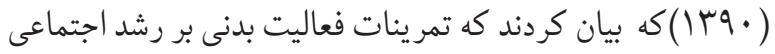

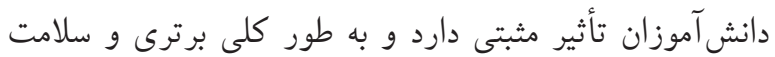

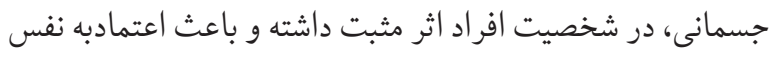

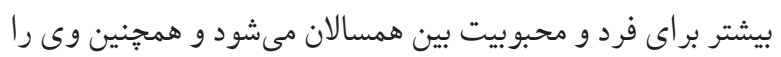
از منزلت اجتماعى ويزه اى بهره مند مى سازد مطابقت دارد(FV).

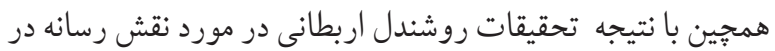

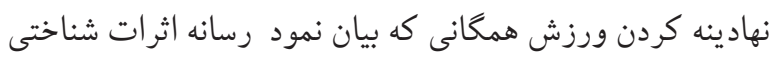
(باورها)، هنجارى ارزشها و تنظيمى (قوانين و مقرر ات در نهادينه سازى ورزش همخانى بر عهده دارد (FN) و ق قاسمى و همكاران بيان مى كنند كه عنوان مى داد تلويزيون در بخشهاى مختلف همدرد

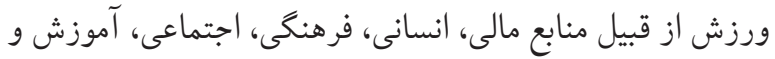

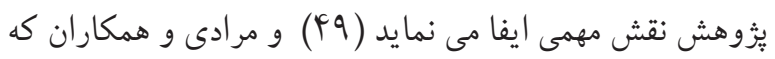

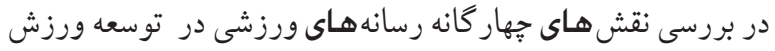
همخانى كه بيان نمودند كه به ترتيب رسانه ها نقش اطلاع رسانى،

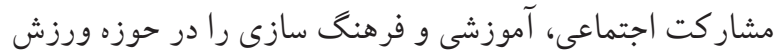

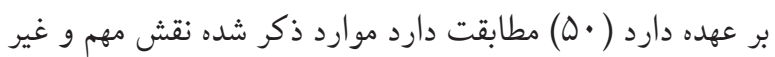

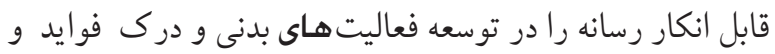

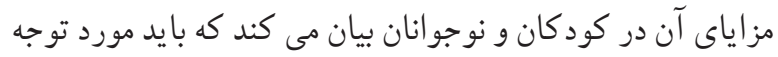

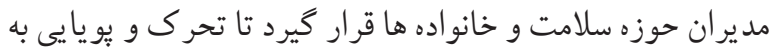
جامعه كودى و نوجوان بركردد.

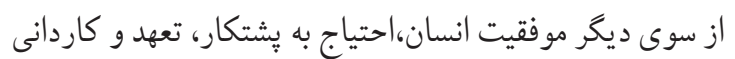

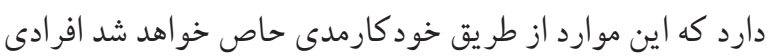

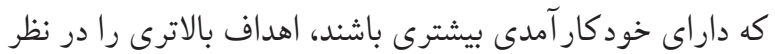
كرفته و متعهدتر گشته و در نتيجه رفتار آنها مطلوب تر مودى شئ شود. در حالى كه اف رادى كه خود كار آمدى بايينى دارند، نتيجه ر فنتار

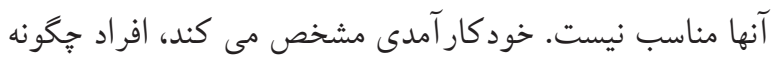

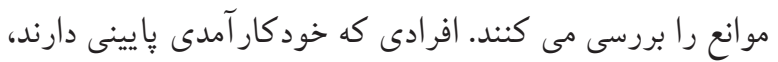

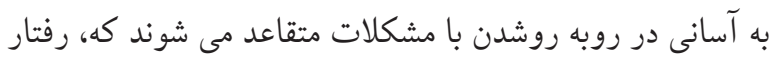

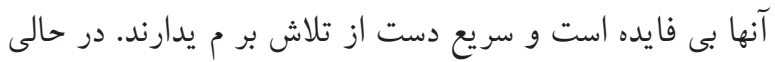

تلو يز يونى بر نكرش كود كان، منفى تأكيد كردند كه كو كان نسبت به جنبهاى خوب و بد تبليغات آكاهى بيشترى دارند و به همين دليل، بايد قبل از تهيه تبليغات، كودكان رادر نظر كرفت (FT).

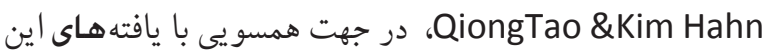
بخش از تحقيق حاضر تحقيق در يُزوهشى با عنوان خودكنترلى

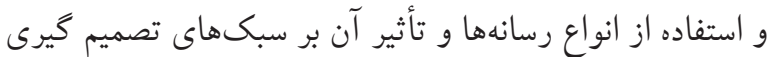
نشان دادند كه ارتباط معنى دارى بين استفاده از شبكه يوتيوب و و سبك كمال كرا وجود دارد. و استفاده از فيسبو دي و سبك دئ آكاهانه

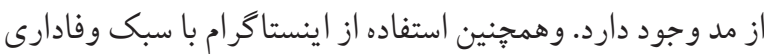
وجود دارد (FF)... درخصوص تأثير مثبت مصرف رسانه اي بر خود كارامدى و و

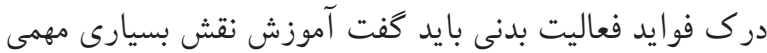

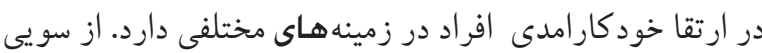

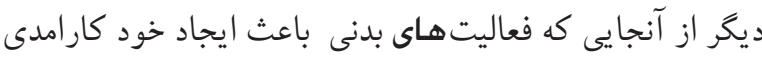

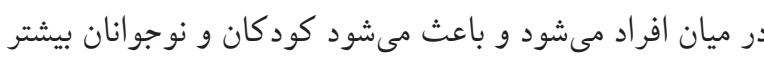

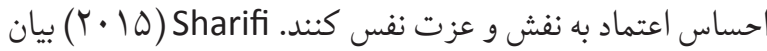
مى كند كه بديهى است كه با افزايش عزت نفس، احساس كفايت،

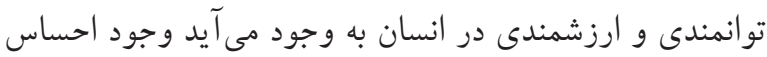

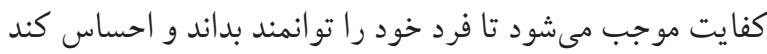
از عهدة بسيارى از وظايفى كه بر عهده اش كذاشته مىشوده، بر مرد

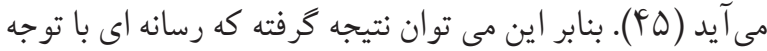

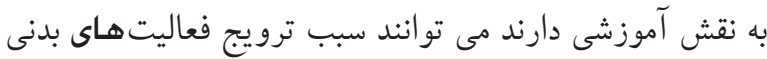

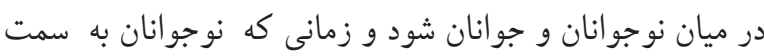

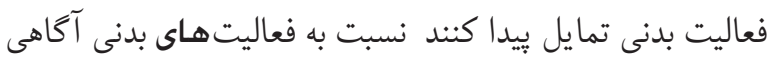
بيشترى ييدا خواهند كرد زيرا دراين زمينه مطالعه خواهند كرد، با افراد ورزشكار بيشتر در ارتباط هستند، بيشتر شبكه هاو اخبار

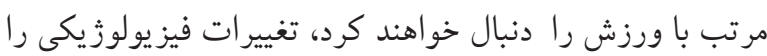

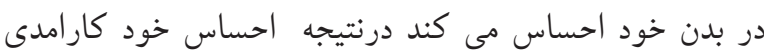

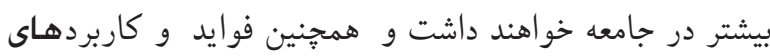
فعاليت بدنى و ورزش را بهتر درك خواهند كرد. اين نتيجه با دورديا نتيجه تحقيق Littlefield (ه • • (Y) كه نقش رسانه هاى تصويرى 
رسانه در فدراسيونهاى ورزشى، تربيت بدنى آموزش ويرورش به توسعه فرهنكى اين ورزش كمك كنند و مسئولان رسانهاى نئ ونيز

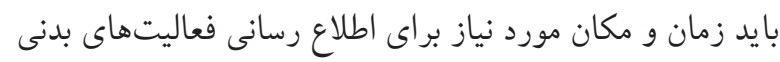

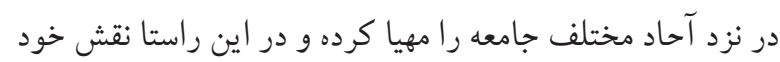
را به درستى ايفا كنند. بـشك اكر كارشناسان رسانهاى در زمينه موضوعات و مسائل روز فعاليتهاى بدنى دانش و شناخت كافى دانى

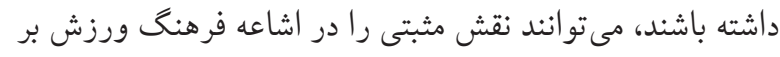

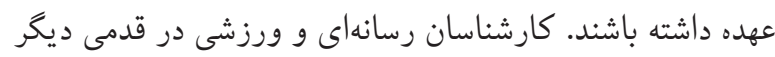

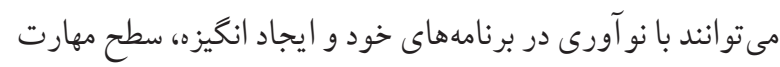

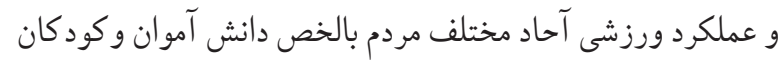

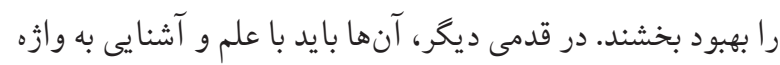

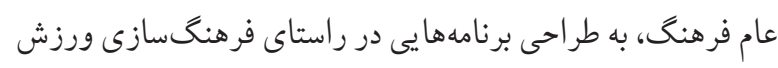

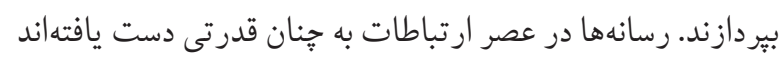

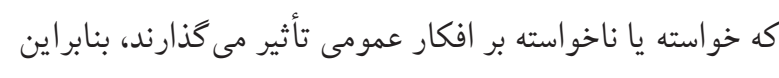

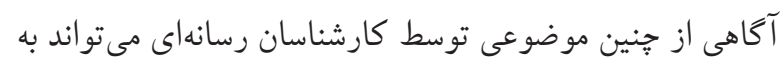
فرهنخ سازى فعاليتهاى بدنى كمك شايانى كند. در اين رائ راستا

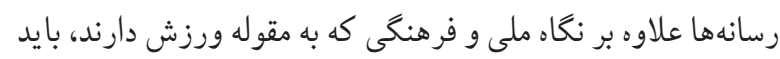

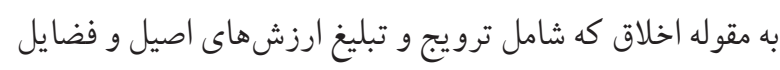
اخلاقى است، توجه ويزماى داشته باشند. فرهنگ سازى در ورزش

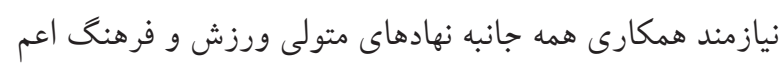

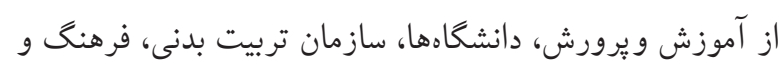

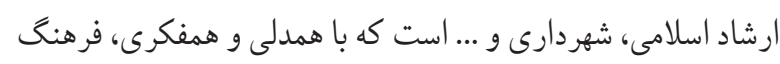

ورزش را در جامعه توسعه بخشند.

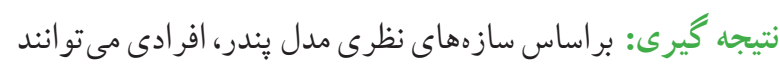

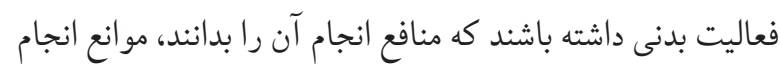

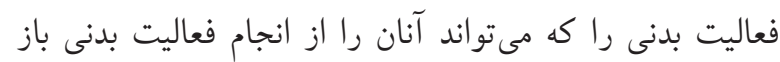

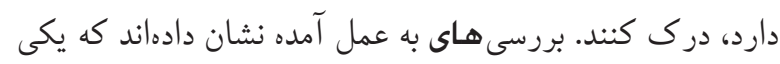

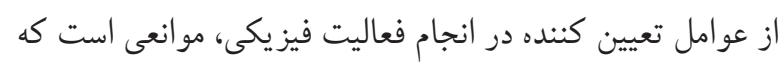

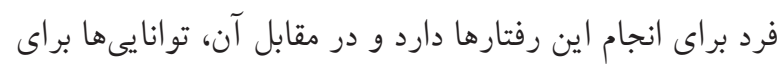

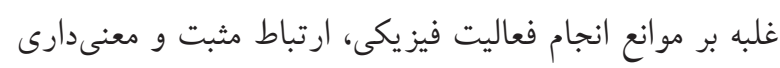

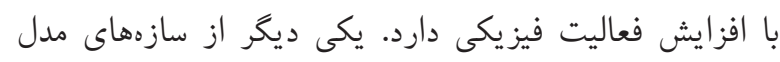

كه افرادى كه خودكار آمدى بالايى دارند، موانع را به وسيله بهبود

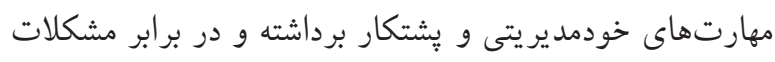

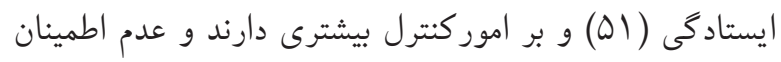

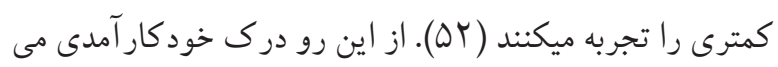

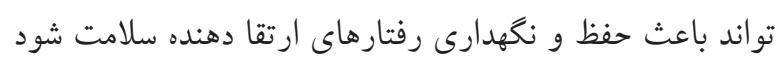

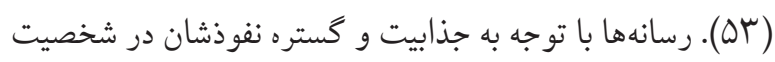
نو جوانان و جوانان، الكوهاى ارزنده و متعالى را به خوبى مى تواند

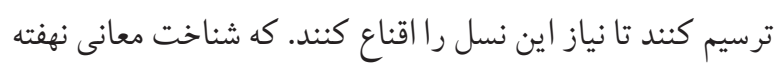

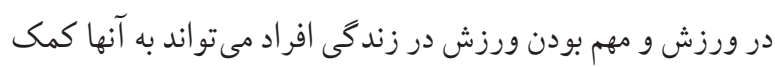

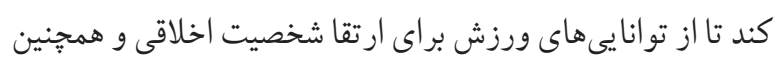

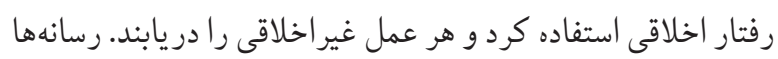

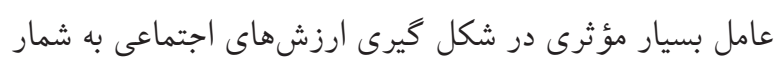

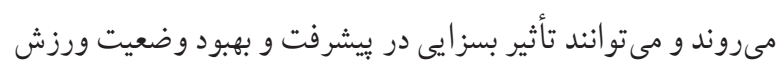

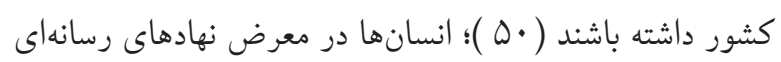

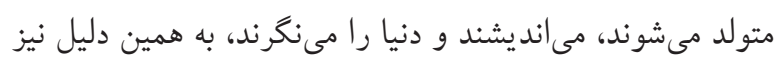

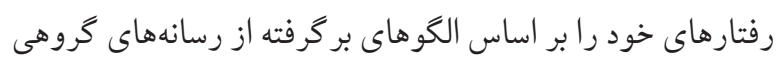

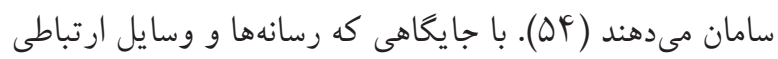

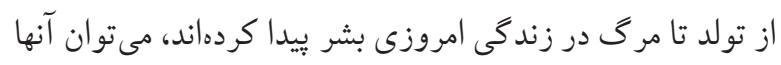

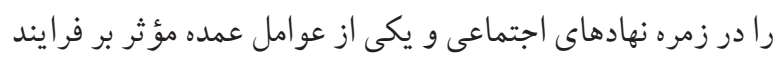

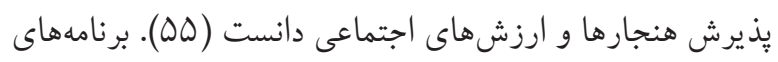

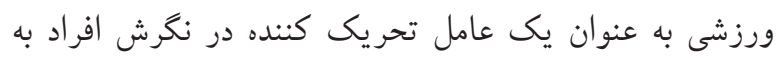

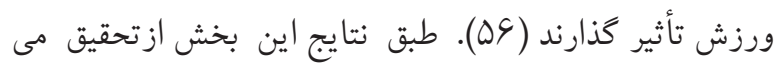

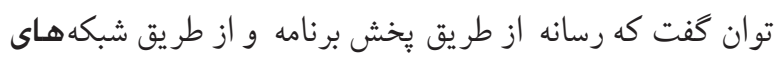

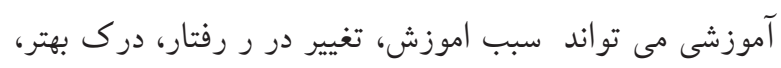

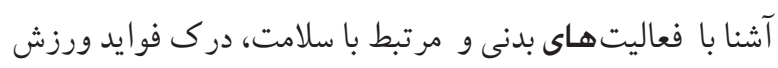

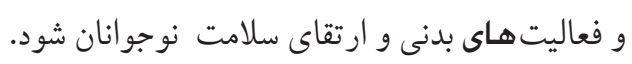
در بايان مىتوان كفت كه مشاركت اجتماعى، آموزشى و و ردان

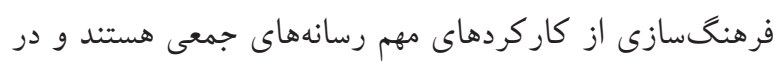

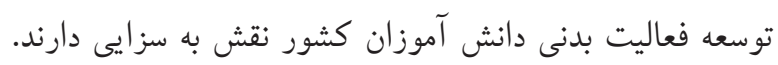

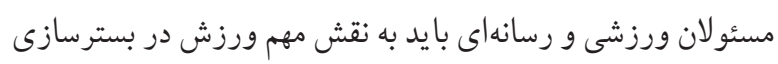
فضاى سلامت و نشاط عمومى جامعه واقف باشند و با تشكيل كميته باني 
based Health Intervention on the promotion of Women's physical activity: a quasi-experimental study. BMC public health. 2018;18(1):1-7. https://doi.org/10.1186/s12889-018-5025-5 PMid:29334970 PMCid:PMC5769504

5. Mohammadpour-Ahranjani B. The epidemiology and prevention of childhood obesity in Tehran, Iran [dissertation]. Birimingham: University of Birmingham. 2011: 54-59.

6. Taymoori P, Falhahi A, Esmailnasab N. Application of the Health Promotion Model in studying physical activity behavior of students in Sanandaj, Iran. Sci J Public Health. 2011; 9(1):35-46

7. Pender NJ, Murdaugh C, Parsons MA. Health promotion in nursing practice. (4th ed). Upper Saddle River, NJ: Prentice-Hall Health Inc. 2002, PP. 58-100.

8. Ma WF, Lane HY, Laffrey SC. A model testing factors that influence physical activity for Taiwanese adults with anxiety. Res Nurs Health. 2008; 31:476-89. https: / / doi.org/10.1002/nur. 20279 PMid:18393350

9. Kelishadi R, Khavarian N, Ghatreh-Samani SH, Beyzaee $M$, Pursafa P, Ramdan R. Effect of different methods of physical activity training for overweight children and adolescents. Knowl Health. 2010; 5(2-3):25-29

10. Levy S.S,Cardinal BJ.Factors Associated with tarnsitional shifts in college students physical activity behavior.Res Q Exerc sport.2006;77(4):476-485 https://doi.org/10.1080/02701367.2006.10599382 PMid:17243222

11. Sabzmakan L, Asghari Jafarabadi M, Nikpajouh A, Bakhtari F. Determinants of Physical Activity among Patients with Cardiovascular Metabolic Risk Factors based on the Educational Factors of PRECEDE Model: A Mixed Method Study. Iranian Journal of Health Education and Health Promotion. 2016;4(1):5-19. https://doi.org/10.18869/acadpub.ihepsaj.4.1.5

12. Wu TY, Pender N. Determinants of physical activity among Taiwanese adolescents: an application of the health promotion model. Res Nurs Health. 2002;25:25-36. h tt p s: / / d o i . org / 10.1002 / n ur. 10021 PMid:11807917

13. Yamaguchi $Y$, Miura $S$, Urata $H$, Himeshima $Y$, Yamatsu $K$, Otsuka $\mathrm{N}$, et al. The effectiveness of a multicomponent program for nutrition and physical activity change in clinical setting: Short-term effects of PACE+ Japan. Int J Sport Health Sci. 2003; 1(2): 229-237. https://doi.org/10.5432/ijshs.1.229
يندر احساس خود كار آمدى است؛ خود كار آمدى عامل پيش بينى كنندهاى در تغيير رفتارهاى مربوط به سلامتى است. بنابر اين و بنابر نتايج اين تحقيق مىتوان عنوان كرد مصرف رسانهاى مى توانند در ارتقاى فعاليت بدنى دانش آموزا نتاثير كذار باشد، جرا الكوى سلامت يندر سازههاى الكوى ارتقاى سلامت را به عنوان تعيين كنندههاى مهم رفتار فعاليت جسمانى معرفى كرده است با توجه به يافتهاى يزوهشى مىتوان نتيجه گرفت براى رسيدن به اهداف توسعه سلامت و فعاليت هاى بدنى دانش آموزان تحت تأثير برنامهاى رسانهها، برنامه سازان و دست اندر كاران

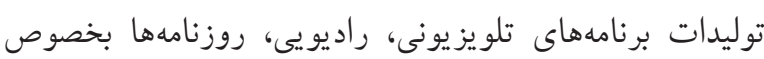
روزنامههاى ورزشى و ديخررسانه ها گروهى بايد به نيازهاى و اولويتهاى ورزشى دانش آموزان توجه كنيد وزئ

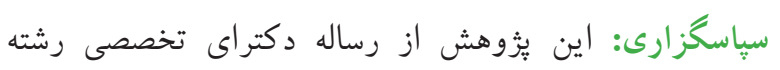
تربيت بدنى گرفته شده است و در معاونت يثروهش دانشگاه يِيام نور تهران تصويب شده است بدين وسيله از معاونت يزوهش

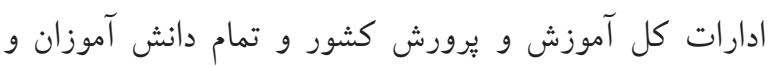
مديران مدارسى كه در اجراى اين تحقيق همكارى داشتند، قدردانى مىشود. تعارض در منافع: سهم تمامى نو يسند گان در اين مطالعه يكسان است و هيج گونه تعارض در منافعى وجود ندارد.

\section{References}

1. Farrar AR, Khani M, Jaberi moghadam AA, Farrokhi A, Sadri $\mathrm{K}$. Levels of physical activity in field-dependent and field independent students. Dev Motor Learn. 2012; 4(9):93110

2. Izadirad H, Zareban I, Masoudy G. The prevalence of low back pain and its relationship with $\mathrm{BMI}$, age, level of education and ergonomic principles education among rural women. Journal of Health Literacy. 2017;1(4):265-72. https://doi.org/10.22038/jhl.2017.10960

3. Chan Sun M, Azmutally KB. Leisure-time physical activity among university students in Mauritius. Am J Health Res. 2013; 1(1): 1-8. https://doi.org/10.11648/j.ajhr.20130101.11

4. Peyman N, Rezai-Rad M, Tehrani H, Gholian-Aval M, Vahedian-Shahroodi M, Miri HH. Digital Media- 
role of mass media in sport development. Adv. Appl. Sci. Res, 2013; 4(4):49-54

25. Thomas M. M; Phongsavan.p; McGill B; J O'Hara Adrian E Bauman,B. A review of the impact of physical activity mass media campaigns on low compared to high socioeconomic groups, Health Education Research.2018; 33(5): 429-446, h tt p s: / / doi .org/10.1093/her/cyy032 PMid:30203025

26. Manz K, Schlack R, Poethko-Muller C, Mensink G, Finger J, Lampert T: Physical activity and electronic media use in children and adolescents: results of the KiGGS study: first follow-up (KiGGS wave 1). Bundesgesundheitsbl Gesundheitsforsch Gesundheitsschutz. 2014;57:840-848 https://doi.org/10.1007/s00103-014-1986-4 PMid:24950833

27. Cummins R, Gong Z. Mediated intra-audience effects in the appreciation of broadcast sports. Commun. Sport. 2017: 5: 27-48. https://doi.org/10.1177/2167479515593418

28. Roshandel Arabtani T, Amiri A. reviewing students media exposure pattern and their impressionability from media aiming at planning for police training programs. Journal societal security studies. 2011; (25): 83 - 105

29. Yanping J. Research on the influence of sports, information, dissemination on public lifetime sports consciousness in the new media inveronment. Adv. Soc. Sci. Educ. Hum. Res. 2015; 35, 295

30. Abbots E, Attala L. It's not what you eat but how and that you eat: Social media, counterdiscourses and disciplined ingestion among amateur competitive eaters. Geoforum, 2017; 84: 188-197 https://doi.org/10.1016/j.geoforum.2014.11.004

31. Moetamed nejhad, K. Mass media. Volume One, Tehran: Allameh Tabataba'i Publications.2012

32. Shahbazi T, Shobeiri S.M, Zandi B..The role of mass media in environmental education from the perspective of secondary-school teachers of Sar-polezahab City. Journal of Environmental Science and Technology.2015; 17(2): 95104

33. Fortes L, Paes, S, Neves, C, Meireles J, Ferreira M. A comparison of the media-ideal and athletic internalization between young female gymnasts and track and field sprinters. J. Clin. Sport Psychol. 2015; 9: 282-291. https://doi.org/10.1123/jcsp.2014-0024

34. Khalil, Ahmad. Media Consumption?. Alternate Solutions Institute, Pakistan.2011; 12: 41-50

35. Saunders M, Lewis, $P$, Thornhill, A. Research methods for business students. Fifth edition. Harlow: Pearson
14. Mansourizadeh M, Anoosheh M, KazemNejad A. The Effect of Physical Activity Program Based on Pender Health Promotion Model on Type 2 Diabetic MiddleAged Women's Mental Health. Iranian Journal of Health Education and Health Promotion. 2018;6(2):159-67. https://doi.org/10.30699/acadpub.ijhehp.6.2.159

15. Sousa P, Gaspar P, Fonseca H, Hendricks C, \& Murdaugh C. Health promoting behaviours in adolescence: Psychometric properties of the Adolescent Lifestyle Profile PT Version. J Pediatr (Rio J). 2015;91(4):358-65.. https://doi.org/10.1016/j.jped.2014.09.005 PMid:25727027

16. Raj S, Senjam SS, Singh A. Assessment of health-promoting behavior and lifestyle of adolescents of a North Indian city. Int J Prev Med. 2013; 4(10): 1189-1193.

17. Ahmad H, AlghadirSami A. Gabr,Zaheen A. IqbalEffects of sitting time associated with media consumption on physical activity patterns and daily energy expenditure of Saudi school students. J Phys Ther Sci. 2015; 27(9). https://doi.org/10.1589/jpts.27.2807 PMid:26504298 PMCid:PMC4616099

18. Aly M.Elen J Willems G. Instructional multimedia program versus sandard lecture. Eur J Dent.2004; 8 (1): 43-6. https://doi.org/10.1111/j.1600-0579.2004.00315.x PMid:14717690

19. Manouchehri Nejad $M$, Hemmati Nejad M,Rahmati $M$, Sharifian I. (2018). Identification and Analysis effective factors of institutionalize sport culture in children and adolescence in view of physical education teachers. J of Sport Management.2018; 10(1): 163-179. (Persian).

20. Arabnarmi, B. (2016). TV and Sport in Daily Life (An Analysis of Linking Media and Sport in Iran). Sport Management.2016; 8(4): 589-603.

21. Shabani A, rezaei M. The effect of media on public sport and recreation. Communication Management in Sports Media. 2015; 3(1) - S. N 9: 24-29

22. Zahiri Nia M, Nikkhah $H$, Shafi'i N. The Effect of Family and Mass Media on Female Students' Participation in Sport Activities (Case Study: Hormozgan University Students) Journal of Participation and Social Development.2016;1(1):61-41

23. Geraee N, Hossen Kaveh M, Shojaeizadeh D; Tabatabaee $\mathrm{H}$. Impact of media literacy education on knowledge and behavioral intention of adolescents in dealing with media messages according to Stages of Change. Journal of Advances in Medical Education \& Professionalism.2017; 3(1): 9-14.

24. Tavakolli M, Najafi A, and Nobakht Ramezani, Z. Studying 
47. Rajaian A, Zahedi H. Effect of 8 weeks physical activity on physical fitness and social development of 4th and 5th grade elementary school students of district of Tehran. Sixth National Conference of Physical Education Students in Iran; 2012 Des 15- 16; Tehran, Iran. Tehran: civilica; 2012

48. Roushandel Arbatani T. The explanation of mass media status in institutionalization of public sports in Iran. Quarterly Harakat 2007; (33): 165-77.

49. Ghasemi H, Mozafari SA, Amirtash AM. Development of sports by TV in Iran. Quarterly Research on Sport Science 2007; 5(17): 131-48.

50. Moradi M, Honari H, Ahmadi A. A survey of fourfold role of sport media in development of sport for all culture. Sport Management 2011; 9: 167-80

51. Baheiraei A, Mirghafourvand M, Mohammadi E, Charandabi SM. The Experiences of Women of Reproductive Age Regarding Health-Promoting Behaviours: A Qualitative Study. BMC Public Health. 2012; 12(1):573. https://doi.org/10.1186/1471-2458-12-573 PMid:22846587 PMCid:PMC3490730

52. Samiei Siboni F, Alimoradi Z, Sadegi T. Impact of Corrective Life Style Education Program on Controlling Stress Anxiety, and Depression in Hypertensive. Journal of Birjand University of Medical Sciences. 2013; 19(6):1-9.

53. Mirghafourvand M, Sehhati F, Rahimi M. Health-Promoting Lifestyle and Its Demographic Predictors in InfertileCouples Referred to Infertility Clinic of Tabriz Al-Zahra Hospital, 2013. Journal of Caring Sciences. 2014; 3(3):175-184.

54. Irajpour A, Mojarrad N, Dabbagh Rezaieh, F. Investigating the Role of Mass Media in Cultural Development of Iran Amateur and Professional Sports. Journal of Sport Management and Development.2017;5(2): 36-52

55. Khaledian M, Mostafaei F, Samadi M, Kia F. The role of mass media in the development of sport. Communication Management in Sports Media.2014;1 (2):48-55

56. Pyun D. Y. The Proposed Model of Attitude toward Advertising through Sport, Electronic Theses, Treatises and Dissertations.2006; P. 637.
Education.2009

36. Hafiz Nina M. R. An introduction to the research method in the Humanities. Tehran: Samt Publications. 2009.

37. Bashiri Moosavi F, Farmanbar R, Taghdisi MH, Atrkar Roshan Z. [Level of physical activity among girl high school students in Tarom county and relevant factors]. Iran J Health Educ Health Prom. 2015;3(2):133-40.

38. Ronis DL, Hong O, Lusk SL. Comparison of the original and revised structures of the Health Promotion Model in predicting construction workers' use of hearing protection. Res Nurs Health. 2006;29(1):3-17. h tt p s: / / d o i.org/10.1002/nur. 20111 PMid:16404731

39. Aghamolaei T, Zare F, Ghanbarnejad A, Haji-Alizadeh K. Relationship of Exercise Benefits/Barriers and self efficacy with stages of change for physical activity in Abu Musa Island employees, Iran. jpm. 2014; 1 (1):31-38

40. Golabi F, Agayari Hir T, Saee M. (1395) Study of the Media's Role in Feeding Behaviorand Its Social Context (Case Study: Citizens Over 15 Years in Tabriz). Journal of Applied Sociology. 2016;27(1): 27-42

41. Brinol P, Petty R.E. Elaboration and Validation Processes: Implications for Media Attitude Change, Media Psychology.2015; 18: 267-291. https://doi.org/10.1080/15213269.2015.1008103

42. Singh D. Impacts of Scary Television Programs on Children Psychology, Attitude and Behavior. New Media and Mass Communication.2014; 23: 5 - 7.

43. Kamal KhanS, Sheheryar S. Impact of TV Advertisement on Children Attitude in Karachi. Journal of Business and Management.2014; 16: 40-46. https://doi.org/10.9790/487X-16934046

44. Tao Q, Hahn, K. Self-Construals, Types of Social Media Usage, and Consumer Decision-Making Styles -- A Study of Young Asian Americans, International Textile and Apparel Association, 2016 ITAA Annual Conference Proceedings. https://doi.org/10.31274/itaa_proceedings-180814-1362

45. Sharifi KH. Designing and Evaluation of psychometric properties of a mental Health Instrument for Middleaged Women [dissertation]. Iran, Tehran: Univ. Tarbait Modares; 2015.

46. Littlefield JH, Damps EL, Keiser K,. Chatterjeel, Yuan $\mathrm{CH}$, Keiser KM. A multimedia patient stimulation for teaching and assessing endodontic diagnosis. J Dent Educ; 2003: 67 (6): 669-77. h ttps://doi.org/10.1002/j.00220337.2003 .67 .6 . t b 03667 . PMid:12856967 